Article

\title{
Trend Analysis of Hydroclimatic Historical Data and Future Scenarios of Climate Extreme Indices over Mono River Basin in West Africa
}

\author{
Djan'na H. Koubodana ${ }^{1,2^{*}}$, Moustapha Tall ${ }^{1,3}$, Ernest Amoussou ${ }^{4}$, Muhammad Mumtaz ${ }^{5}$ Julien \\ Adounkpe $^{1}$, Kossi Atchonouglo ${ }^{2}$ \\ ${ }_{1}$ West Africa Science Service Centre on Climate change and Adapted Land Use, WASCAL-Climate Change and \\ Water Resources, University of Abomey Calavi, 03 BP 526 Cotonou, Benin; koubo2014@gmail.com; \\ julvictoire@yahoo.com \\ 2 Faculty of Sciences, University of Lomé, Po. Box 1515 Lomé, Togo; kossi.atchonouglo@gmail.com \\ 3 Laboratoire de Physique de l'Atmosphère et de l'Océan, Ecole Supérieure Polytechnique, Université Cheikh \\ Anta Diop, Dakar, Senegal; tall.moustapha89@gmail.com \\ 4 Laboratoire Pierre PAGNEY, Climat, Eau, Ecosystème et Développement (LACEEDE), 03 BP1122, Cotonou, \\ Bénin; ernestamoussou@gmail.com \\ 5 Department of Public Administration and Government, Getulio Vargas Foundation, Sao Paulo, Brazil; \\ mumtaz86@hotmail.com
}

*Correspondence: koubo2014@gmail.com; Tel: +228 90-97-80-71

Received: date; Accepted: date; First Version Published: date

\begin{abstract}
This paper performs non-parametric Mann Kendall (MK) trend analysis of historical hydroclimatic data (1961-2016), an ensemble climate model validation and a computation of 16 Expert Team on Climate Change Detection and Indices (ETCCDI) temperature and rainfall extremes indices. The climate indices are evaluated using MK test and annual trend analysis for two Representative Concentration Pathways (RCP4.5 \& RCP8.5) future scenarios from 2020 to 2045 over Mono River Basin (MRB) in Togo. The annual and seasonal trend analyses are assessed on historical potential evapotranspiration, mean temperature, rainfall and discharge data. Results show positive and negative trends of hydroclimatic data over MRB from1961 to 2016. Mean temperatures increase significantly in most of the stations while a negative non-significant trend is noticed for rainfall. Meanwhile, the discharge presents a significant seasonal and annual trend for three gauge stations (Corrokope, Nangbéto and Athiémé). Validation of the ensemble climate models reveals that the model under-estimates observations at Sokode, Atkakpamé and Tabligbo stations, however linear regression and spatial correlation coefficients are higher than 0.6. Moreover, the percentage of bias between climate model and observations are less than $15 \%$ at most of the stations. Finally, the computation of extreme climatic indices under RCP4.5 and RCP8.5 scenarios shows a significant annual trend of some extreme climatic indices of rainfall and temperature at selected stations between 2020 and 2045 in the MRB. Therefore, relevant governmental politics are needed to elaborate strategies and measures to cope with projected climate changes impacts in the country.
\end{abstract}

Keywords: Trend analysis, Extremes indices, Climate change, ETCCDI

\section{Introduction}

According to Intergovernmental Panel on Climate Change (IPCC,2014) [1], climate change is due to natural and anthropogenic factors. The emissions of greenhouse gas (GHG) from anthropogenic activities increases temperature and affect precipitation frequencies [2-5]. Therefore, it is important to evaluate the long-term change of hydroclimatic variables to track their impacts on natural water resource and biodiversity.

A set of historical and present state of hydroclimatology can be analyzed through climate model and Representative Concentration Pathways (RCPs) scenarios impact studies. Many previous studies 
already demonstrated that West Africa have suffered from extreme events [6,7]. For example, West Africa has experimented drought of 1970s and 1980s and recently floods events [8]. Ciais et al. [9] also highlighted a dry trend over West Africa in a long period from 1951 to 2012.

Trend analysis of climate variables is common assessed by hydrologists or climatologists using Global Climate Models (GCMs) and or Regional Climate Models (RCMs) from global to local scales. GCMs are more global, coupled with atmospheric and ocean model reflects the earth climate system However, local impact studies rarely used GCMs outputs without downscaling GCMs. This is due of errors from the limited spatial resolution, simplified physics, thermodynamic processes and numerical schemes. Thus, downscaling and bias correction of GCMs from high to small grids are more representative local agriculture, biodiversity or hydrological modeling analysis. Many downscaling methods were cited such as bias correction with variability; bias correction no variability, change factor no variability, change factor no variability, quantiles mapping and raw data [10-12]. A number of studies have concluded better performances of quantiles mapping for precipitation data and bias correction with variability for temperature [11,13-15].

Parametric or non-parametric trend analysis methods trough a statistical approach is frequently used for trend detection by fixing a certain level of confidence. Several studies have been addressed regarding trend analysis of climatic variables at global scale of a watershed. For example, Yan and Bai [4] in China found a decrease and an increase of flood precipitation and non-flood precipitation between 1969 to 2011. Afterward, Gocic and Trajkovic [16] obtained a negative and positive trend of streamflow for the last 50 years and comparing factors due to human activities and climate change. In west and south Africa, Gosling et al. [17] analyzed the trend in daily climate extremes and have observed an evident warming over most of the region. Oguntunde et al. [18] determined an increase of runoff trend with significant by analyzing the long-term trend hydro-climatology of Volta river basin in west Africa from 1901 to 2002. Diallo et al. [19] analyzed the inter-annual variability using several climate models over Sahel region and concluded that the models can reproduce rainfall variability with correlation exceeding 0.6 compare to observations. Amoussou et al. [20] reviewed hydroclimatic variability and flood risk in two small forests located in the Mono River Basin (MRB). Lawin et al. [21,22] studied climate extreme trends of temperature and rainfall using a single model of Coordinated Regional Downscaling Experiment (CORDEX) and later with REgional MOdel (REMO) and consedering a few number of stations in the MRB. These studies pointed out an increase of temperature and a high variability of rainfall for historical and future baseline. According to the literature, in the MRB, fewer studies incorporated water balance components and as well an ensemble of climatic models for future scenarios of extreme indices.

The present study analyzes a set of historical hydroclimatic data over MRB in order to investigate trend in streamflow, rainfall, potential evapotranspiration and mean temperature over MRB after a pre-validation of multi-model ensemble and a computation of future scenarios climatic extreme indices.

The method adopted is Man-Kendall (MK) test trend on historical and extreme indexes computation using RclimDex package. MK method was used widely and has demonstrated to be reliable for trend analysis for long climatic time series [23-26].

Section 2 provides (i) a description of the study area, (ii) hydroclimatic data and climatic model description, (iii) MK methodology description, ensemble climatic model validation and future scenarios climatic extremes indices computation. Section 3 presents the results of MK trend analysis applied on hydroclimatic variables, ensemble climatic model temporal and spatial validation as well of future projection of extreme indices and section 4 provides perspectives and future directions.

\section{Materials and Methods}

\subsection{Study area}

The MRB is the second largest river in Togo, which is shared with Benin Republic. The basin is located between $6.16^{\circ}$ and $9.2^{\circ} \mathrm{N}$ and $0.42^{\circ}$ and $1.40^{\circ} \mathrm{E}$ (Figure 1). The whole river basin represents $38 \%$ and $2.14 \%$ area of Togo and Benin Republics respectively. At the outlet at Athiémé, the basin 
covers an area of $22,014 \mathrm{~km}^{2}$ with $88 \%$ of its area in Togo and $12 \%$ in Benin [27]. The MRB is $309 \mathrm{~km}$ long, has its source in the Alédjo mountains [28] in the north of Benin and drains into the Atlantic Ocean vias "Boca Del Rio". The elevation of the basin ranges from 12 to 948 meters (http://srtm.csi.cgiar.org/). The biggest dam on the way of this river is at Nangbéto and produces $20 \%$ of the total hydroelectricity used by Togo and Benin.

The watershed area encompasses two climate zones. In the south, from $6^{\circ}$ to $8^{\circ} \mathrm{N}$ two rainy seasons and two dry seasons exist with mean rainfall between 1200 and $1500 \mathrm{~mm} /$ year in the mountainous area of the south-west and 800 to $1000 \mathrm{~mm} /$ year in the coastal zone [29].

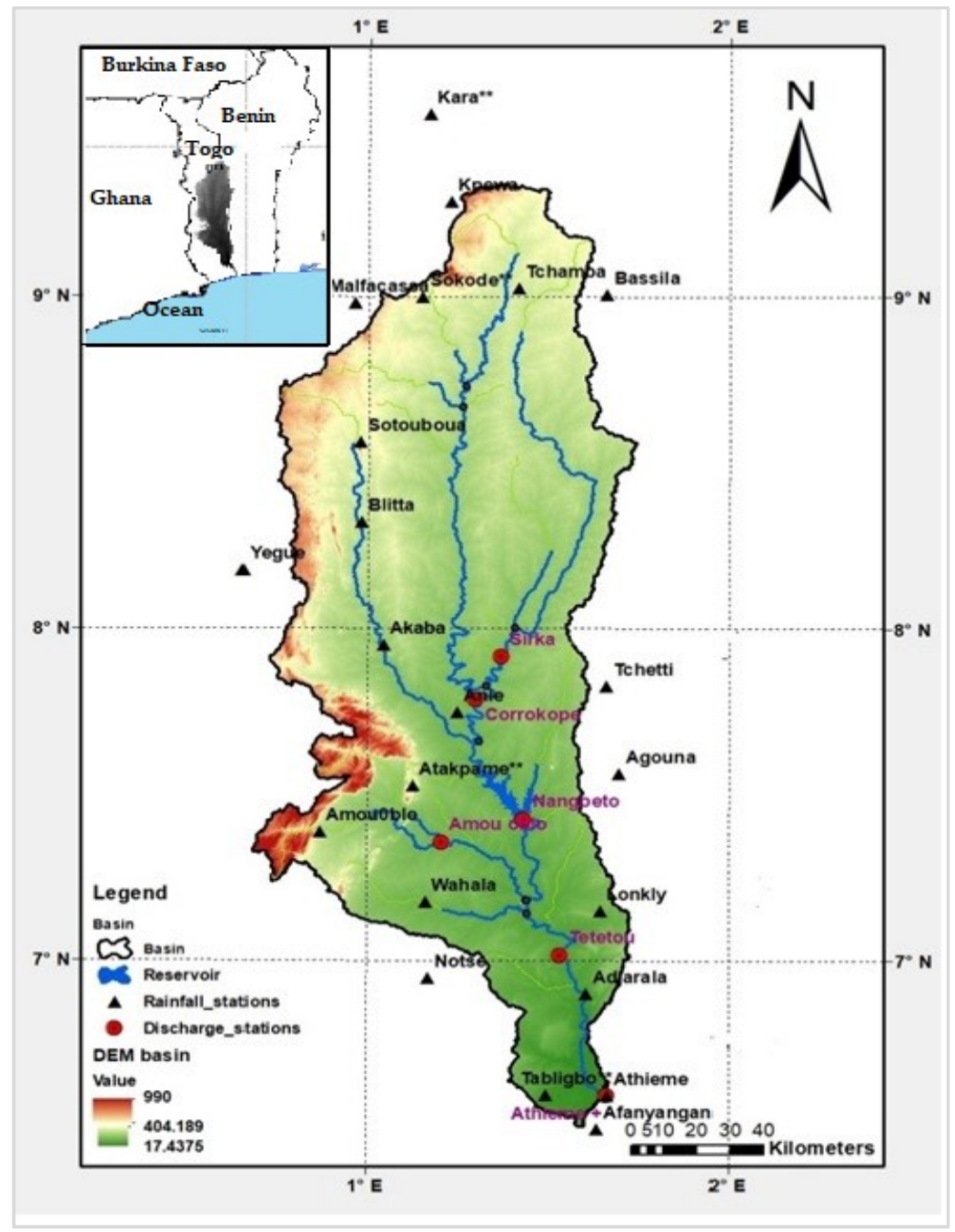

Figure 1. Location of the study

The natural vegetation is mainly savanna and is composed of the bush and tree savanna, gallery forests and grassland [30]. The relief is generally flat except for the mountainous regions of the West and the Northwest

In 2011, the MRB is populated by about 5.1 Million inhabitants. The main socio-economic activities are agriculture, trade, fisheries and livestock husbandry [27,31,32]. According to FAO, the population in Togo has triplicate since 1975 and it is constantly increasing in future (http://worldpopulationreview.com/countries/togo-population).

\subsection{Data}

2.2.1. Discharge 
Daily discharge data are analyzed for the trend analysis in this study and are collected at General Direction of Water and Sanitation of Togo (DGEA-Togo), Central Electric of Benin (CEB) and General Direction of Water of Benin (DGEau-Benin), abbreviations in French.

The maximum of discharge usually occurs between August and September corresponding to the maximum rainfall in the basin. Details regarding hydrologic data are provided in Table 1.

Table 1. Discharge data station available in MRB

\begin{tabular}{|c|c|c|c|c|c|c|c|c|}
\hline \multirow[t]{2}{*}{$\mathbf{N}_{\mathrm{o}}$} & \multirow{2}{*}{$\begin{array}{l}\text { Station } \\
\text { Name }\end{array}$} & \multirow[t]{2}{*}{ Source } & \begin{tabular}{|l} 
Long. \\
(m)
\end{tabular} & Lat. (m) & \multirow{2}{*}{$\begin{array}{c}\text { Elevation } \\
\text { (m) }\end{array}$} & \begin{tabular}{|l|}
$\begin{array}{l}\text { Discharge } \\
\left(\mathrm{m}^{3} / \mathrm{s}\right)\end{array}$ \\
\end{tabular} & \multirow{2}{*}{$\begin{array}{l}\text { Area } \\
\left(\mathrm{km}^{2}\right)\end{array}$} & \multirow[t]{2}{*}{ Period } \\
\hline & & & East & North & & Max & & \\
\hline 1 & Corrokopé & \begin{tabular}{|l} 
DGEA- \\
Togo
\end{tabular} & 1.36 & 7.78 & 196 & 844 & 9904 & 1961-1998 \\
\hline \multirow{2}{*}{2} & $\begin{array}{l}\text { Nangbéto } \\
\text { inflow }\end{array}$ & \multirow{2}{*}{ CEB } & \multirow{2}{*}{1.52} & \multirow{2}{*}{7.67} & \multirow{2}{*}{150} & 2133 & \multirow{2}{*}{1560} & \multirow{2}{*}{ 1988-2011 } \\
\hline & $\begin{array}{l}\text { Nangbéto } \\
\text { outflow }\end{array}$ & & & & & 1428.55 & & \\
\hline 3 & Athiémé & \begin{tabular}{|l} 
DGEau- \\
Benin
\end{tabular} & 1.67 & 6.57 & 11 & 951 & 22014 & 1961-2011 \\
\hline
\end{tabular}

\subsubsection{Climatic data}

Historical daily rainfall data of 21 rain gauge stations are collected at General Direction of Meteorology of Togo (DGMN-Togo) and National Meteorology Agency of Benin (METEO-Benin), all the abbreviations are in French. We have collected minimum and maximum temperature (1961-2016) of three meteorological stations from Togo (Table 2). The period of 1961 to 2016 is chosen because of the availability of the data with fewer gaps. There selected stations daily missing value is less than $10 \%$. rainfall missing values are filled by using Pearson correlation with a neighboring station [33]. The daily values of potential evapotranspiration (PET) collected at DGMN- Togo are available only for three stations between 1981 and 2016 (Table 2). PET is computed using Hargreaves method [34] which requires only minimum and maximum temperature $[35,36]$.

Monthly values are computed by average of daily temperature, discharge and PET or cumulative for rainfall. Finally, we divided a year in four sub periods: spring as MAM (March, April and May), summer as JJA (June, July and August), autumn as SON (September, October and November) and winter as DJF December, January and February.

Table 2. Detail of climatic stations used.

The alphabets $R$ and $M$ are for rain gauge and meteorological stations, respectively. 


\begin{tabular}{|c|c|c|c|c|c|c|c|c|c|c|c|}
\hline \multirow{2}{*}{$\mathrm{No}$} & \multirow{2}{*}{ Station name } & \multirow{2}{*}{ Source } & \multirow{2}{*}{\begin{tabular}{|l} 
Long.(m) \\
East \\
\end{tabular}} & \multirow{2}{*}{\begin{tabular}{|l|} 
Lat. $(\mathrm{m})$ \\
North \\
\end{tabular}} & \multirow[t]{2}{*}{ Elevation $(\mathrm{m})$} & \multicolumn{2}{|c|}{ Daily Rainfall } & \multicolumn{3}{|c|}{ Daily Mean Temperature } & \multirow{2}{*}{ Type } \\
\hline & & & & & & Max & Std CV [\%] & Max Min & Std & CV [\%] & \\
\hline 1 & Kara & DGMN-Togo & 1.17 & 9.55 & 342.00 & 196.90 & $9.51 \quad 37.56$ & & & & \\
\hline 2 & Kpewa & DGMN-Togo & 1.25 & 9.2 & 729.00 & 163.10 & $9.42 \quad 40.04$ & & & & $\bar{R}$ \\
\hline 3 & Tchamba & DGMN-Togo & 1.42 & 9.03 & 360.00 & 160.50 & $9.69 \quad 33.53$ & & & & $\mathrm{R}$ \\
\hline 4 & Sokode & DGMN-Togo & 1.12 & 8.98 & 400.00 & 142.60 & 38.35 & $34.3 \quad 20.4$ & 1.9 & 7 & $R \& M$ \\
\hline 5 & Malfacassa & DGMN-Togo & 0.96 & 8.98 & 405.97 & 146.40 & \begin{tabular}{|ll}
8.79 & 41.85 \\
\end{tabular} & & & & $\mathrm{R}$ \\
\hline 6 & Bassila & METEO-Benin & 1.67 & 9.02 & 384.00 & 129.10 & 34.17 & & & & $R$ \\
\hline 7 & Sotouboua & DGMN-Togo & 0.98 & 8.57 & 380.00 & 145.00 & 10.3736 .30 & & & & $\mathrm{R}$ \\
\hline 8 & Blitta & DGMN-Togo & 0.98 & 8.32 & 307.26 & 120.00 & $\begin{array}{|ll|}8.92 & 39.45 \\
\end{array}$ & & & & $\mathrm{R}$ \\
\hline 9 & Yegue & DGMN-Togo & 0.65 & 8.17 & 594.35 & 108.90 & 7.61 & & & & $R$ \\
\hline 10 & Akaba & DGMN-Togo & 1.04 & 7.95 & 225.87 & 142.50 & $\begin{array}{|ll|}8.28 & 38.44 \\
\end{array}$ & & & & $\mathrm{R}$ \\
\hline 11 & Tchetti & METEO-Benin & 1.72 & 7.63 & 353.00 & 118.00 & 10 & & & & $\mathrm{R}$ \\
\hline \begin{tabular}{|l|}
12 \\
\end{tabular} & Anie & DGMN-Togo & 1.25 & 7.75 & 160.00 & 149.50 & $9.29 \quad 33.47$ & & & & $\mathrm{R}$ \\
\hline 13 & Agouna & METEO-Benin & 1.70 & 7.55 & 240.00 & 162 & 10.2931 .32 & & & & $\bar{R}$ \\
\hline 14 & Atakpame & DGMN-Togo & 1.12 & 7.58 & 400.00 & 157 & $10.53 \quad 35.70$ & 35 & 1.8 & 7 & $\mathrm{R} \& \mathrm{M}$ \\
\hline 15 & Amou & DGMN-Togo & 0.87 & 7.386 & 291.60 & 104 & $\begin{array}{|ll|}8.47 & 36.47 \\
\end{array}$ & & & & $\mathrm{R}$ \\
\hline 16 & Wahala & DGMN-Togo & 1.16 & 7.176 & 144.69 & 118 & 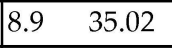 & & & & $\mathrm{R}$ \\
\hline 17 & Lonkly & METEO-Benin & 1.65 & 7.15 & 110.00 & 118 & $10.12 \quad 31.87$ & & & & $\mathrm{R}$ \\
\hline 18 & Notse & DGMN-Togo & 1.18 & 6.95 & 150.00 & 157 & 10.1432 .81 & & & & $\mathrm{R}$ \\
\hline \begin{tabular}{|l|}
19 \\
\end{tabular} & Adjarala & METEO-Benin & 1.61 & 6.90 & 52.00 & 185 & $\begin{array}{|ll|}11.02 & 39.7 \\
\end{array}$ & & & & $\mathrm{R}$ \\
\hline 20 & Tabligbo & DGMN-Togo & 1.51 & 6.59 & 51.00 & 117 & $9.04 \quad 31.77$ & $\begin{array}{|ll|}35.1 & 19.3 \\
\end{array}$ & 1.7 & 6.3 & $\mathrm{R} \& \mathrm{M}$ \\
\hline 21 & Afanyangan & DGMN-Togo & 1.63 & 6.49 & 72.19 & 192 & 31.3 & & & & $\bar{R}$ \\
\hline
\end{tabular}

2.2.3. Climate model used

In this study, downscaled and bias corrected historical daily temperature and rainfall (1980-2005) The RCP4.5 \&RCP8.5 future scenarios (2020-2045) provided by Climate Change Agriculture and Food Security (CCAFS) portal (http://ccafs-climate.org/data bias correction/) are used. The model data are from Global Climate Models (GCMs) derived from Princeton Reanalysis datasets. Princeton Reanalysis is a meteorological forcing dataset which is used to drive GCMs for land surface hydrology studies (Table 3). The dataset is constructed by combining a suite of global observation-based datasets with the National Center for Environmental Predictions/ NCEP/NCAR reanalysis.

Table 3. Global climate models used for ensemble model generation

\begin{tabular}{|l|l|l|l|}
\hline Model Centre & Model & $\begin{array}{l}\text { Resolution } \\
\text { (Long \& Lat) }\end{array}$ & References \\
\hline $\begin{array}{l}\text { Beijing Climate Center, China } \\
\text { Meteorological Administration }\end{array}$ & BCC_CSM1_1 & $2.79 \times 2.80$ & {$[37]$} \\
\hline Max Plank Institute for Meteorology & MPI-ESM-MR & $1.87 \times 1.88$ & {$[38]$} \\
\hline $\begin{array}{l}\text { Japan Agency for Marine-Earth Science } \\
\text { and Technology, Atmosphere and } \\
\text { Ocean Research Institute }\end{array}$ & MIROC_ESM & $2.79 \times 2.81$ & {$[39]$} \\
\hline $\begin{array}{l}\text { NOAA Geophysical Fluid Dynamics } \\
\text { Laboratory }\end{array}$ & GFDL-ESM2M & $2.00 \times 2.50$ & {$[40]$} \\
\hline
\end{tabular}

\subsection{Methods}

2.3.1. Computation of mean hydroclimatic data over the whole MRB 
A primary analysis is conducted using the average of three stations of PET and temperature in the MRB. The mean rainfall over MRB is obtained by computing Thiessens polygons [41] using 21 stations of MRB.

In order to achieve accurate estimation of rainfall over the whole basin, it is necessary to use Thiessen polygons methods. Thiessen polygons method assigns weight at each gauge station in proportion to the catchment area that is closest to that gauge. The method of constructing the polygons implies the following steps:

(i) Gauge network is plotted on map of the catchment area of interest.

(ii) Adjacent stations are connected with lines

(iii) Perpendicular bisectors of each line are constructed (perpendicular line at the midpoint of each line connecting two stations)

(iv) The bisectors are extended and used to form the polygon around each gauge station

(v) Rainfall value for each gauge station is multiplied by the area of each polygon

(vi) All values from step (v) are summed and divided by total basin area.

2.3.2. Test of auto-correlation of hydroclimatic time series.

Initially, auto-correlation test is applied on hydroclimatic time series for determining the randomness of the data. This criterion involves using parametric and non-parametric methods for trend analysis. Therefore, depending for the correlation coefficient values ranges $(0 \leq \mathrm{r} 1 \leq 1)$, parametric or nonparametric MK test is used [42]. For this analysis two methods MK and Sen's estimator were used to evaluate the variables trend for a long period.

\subsubsection{Mann Kendall (MK) trend analysis}

The method consists to compute a climatic index and apply Non-parametric MK test for trend detection analysis with MAKESENS version 1.0 application developed by Finnish Meteorological Institute [43] for MK test and slope estimation. The method was applied successfully in many studies around the world $[18,44-46]$. In this study, analysis is applied on mean temperature, rainfall and PET series over the MRB.

The MK test analysis S [47] is computed as:

$$
S=\sum_{i=1}^{n-1} \sum_{j=j+1}^{n} \operatorname{sgn}\left(X_{j}-X_{i}\right)
$$

With $n$ the number of data point, $X i$ and $X_{j}$ are the data values in the time series $i$ and $j(j>i)$, and $s g n$ $\left(X_{j}-X_{i}\right)$ is the sign of the following system:

$$
\operatorname{sgn}\left(X_{j}-X_{i}\right)=\left\{\begin{array}{c}
+1, \text { if } X_{j}-X_{i}>0 \\
0, \text { if } X_{j}-X_{i}=0 \\
-1, \text { if } X_{j}-X_{i}<0
\end{array}\right.
$$

This statistic computes the number of positive differences minus the negative differences for all the differences considered. The variance is computed as:

$$
\operatorname{Var}(S)=\frac{n(n-1)(2 n+5)-\sum_{i=1}^{m} t_{i}\left(t_{i}-1\right)\left(2 t_{i}+5\right)}{18}
$$

Where $\mathrm{n}$ is the number of data point available, $\mathrm{m}$ is the number of tried groups in the series and $\mathrm{t}_{\mathrm{i}}$ denotes the number of ties of extent $i$. A tried group is defined as the set of sample data that have the same value. If no ties between observations are present and no trends in the time series, the test statistic is asymptotically normal distributed with:

$$
V(s)=\frac{n(n-1)(2 n+5)}{18}
$$


For the case where the size of the sample data is bigger than $10(n>10)$, the standard normal test statistic $Z_{s}$ is computed using the flowing equation:

$$
Z s=\left\{\begin{array}{l}
\frac{s-1}{\sqrt{\operatorname{Var}(S)}}, \text { if } S>0 \\
0 \quad \text { if } S=0 \\
\frac{s+1}{\sqrt{\operatorname{var}(S)}}, \text { if } S<0
\end{array}\right.
$$

A positive value of $Z s$ shows the increase of the trend while a negative value indicates the decrease of trends. To test the trend, $\alpha$ significant level can be used. When $\left|Z_{s}\right|>Z_{1-\alpha / 2}$, the null hypothesis is rejected and a significant trend exists in the time series. $Z_{1-\alpha / 2}$ is computed by from the standard normal distribution table. In this study we used $\alpha=99 \%$ and $\alpha=95 \%$. So at $5 \%$ significance level the null hypothesis of no trend is rejected if $\left|Z_{s}\right|>1.96$ and rejected if $\left|Z_{s}\right|>2.576$ at $1 \%$ significance level.

\subsubsection{Sen's slope estimator}

Sen and Niedzielski [48] has developed the non-parametric procedure in order to estimate the slop of trend in the sample of $\mathrm{N}$ pair of data.

$$
\mathrm{Qi}=\frac{x_{j-X_{k}}}{J-k} \text { fori }=1, \ldots, N,
$$

where $X_{j}$ and $X_{k}$ are the data value at tile $j$ and $k(j>k)$, respectively.

If there is only one datum in each, time period, the $\mathrm{N}=\frac{n(n-1)}{2}$,

where $\mathrm{n}$ is the number of periods. If there are multiple observations, the $\mathrm{N}$ values of $\mathrm{Q}$ are ranked from smallest to largest and the median of slop or Sen's estimator is computed as

$$
\mathrm{Q}_{\mathrm{med}}=\left\{\begin{array}{c}
Q_{\left[\frac{N+1}{2}\right], \quad \text { if } N \text { is odd }} \\
\frac{Q_{\left[\left(\frac{N}{2}\right)\right]}+Q_{\left[\frac{N+2}{2}\right]}}{2}
\end{array} \text {, if } N\right. \text { is even }
$$

The $Q_{\text {med }}$ sign reflects data trend reflection, while its value indicates the steepness of the trend. To determine whether the median slope is statistically deferent than zero, one should obtain the confidence interval of $\mathrm{Q}_{\mathrm{med}}$ at specific probability.

The confidence interval about the tile slope [49] can be defined by:

$$
C_{\alpha=Z_{1-\alpha / 2} \sqrt{\operatorname{Var}(S)}}
$$

where $\operatorname{Var}(\mathrm{S})$ is defined in equation (4) and $\mathrm{Z}_{1-\alpha / 2}$ is obtained from the standard normal distribution table. In this study, the confidence interval is computed at two significance level ( $\alpha=99 \%$ and $\alpha=$ $95 \%)$.

Then, $M 1=\frac{N-C \alpha}{2}$ and $M 2=\frac{N+C \alpha}{2}$ are computed. The lower and upper limits of the confidence interval, $\mathrm{Q}_{\min }$ and $\mathrm{Q}_{\max }$ are the $\mathrm{M}^{{ }^{\mathrm{th}}}$ largest and the $\left(\mathrm{M}_{2}+1\right)^{\text {th }}$ largest of the $\mathrm{N}$ ordered slope estimates.

The slope $Q_{\operatorname{med}}$ is statistically different than zero if the two limits ( $Q_{\min }$ and $\mathrm{Q}_{\max }$ ) have similar sign. Sen's slope estimator has been widely in hydroclimatic time series $[18,26,36]$.

\subsubsection{Ensemble climate model validation}

Validation gives the fitness between model outputs and observation data and indicates the confidence of future scenarios results. A very good spatial and temporal representation of the ensemble mean climate model and observation data involves that data from the model can be used for future scenarios impacts in this region [50,51]. In the study downscaled and bias corrected ensembles mean GCM is validated though the observation data get from the meteorological services from Togo 
and Benin. Monthly and annual data from the observation plotted against ensemble climate model value and by determining the coefficient of determination values between observation and model. Additionally the ratio with observation of the difference between ensemble model and observations (bias) was performed during the same period to determine if the change is sensitive or not as well monthly and annual time steps [13]. A value of bias values lower than $\pm 10 \%$ shows a perfect model, between $\pm 10 \%$ and $\pm 15 \%$ indicate a good model, whereas value greater than $\pm 25 \%$ indicate an unsatisfactory model prediction [52].

The period of validation (1980-2005) is chosen where model outputs and observation data are both available and without gaps [10]. The linear regression coefficient of observations against model output was computed at each station of mean temperature and rainfall data.

The spatial distribution of rainfall ensemble climate model data against observation data were mapped for two periods JJA and DJF. Kriging interpolation method developed in ArcGIS 10.5 is used for rainfall spatial distribution [53-56]. Kriging is a linear interpolation method which allows to estimate areal values as a weighted mean of observations [57]. Contrary to precipitation, temperature number observed station cannot be used for spatial validation.

\subsubsection{Data quality control and future scenarios extreme indices computation}

The important key for indices concept is the calculation of the temperature and rainfall indices with a fixed threshold. The indices calculation aim is to monitor climate change and detections. Initially 27 cores indices are recommended by CCI/CLIVAR Expert Team for Climate Change Detection Monitoring and Indices (ETCCDI). RClimDex allows a rapid analysis of data quality before indices calculation. Data quality corrects all the unreasonable values, missing value, negatives precipitation and temperature and identifying outliers of daily values outside of user region. More information about the indices and its computation developed by Expert Team on Climate Risk and Sector-specific Climate Indices can be found on http://wwww.wmo.int/pages/prog/wcp/ccl/opace/opace4/expertteam.php.

In this study, we used the RClimDex (Version 1.0) package in $\mathrm{R}$ environment ( version 1.1.463) developed by Zhang and Yang [58]. A total number of sixteen (16) indices of temperature and rainfall computed were evaluated by non parametric MK test and annual trend analysis for two climate scenarios RCP4.5 \& RCP8.5. Only three representatives' climate stations of MRB (Tabligbo, Atakpamé and Sokodé) were selected for extreme indice analysis. Table 3 shows the selected indices and definition. RClimDex is available through http://cccma.seos.uvic.ca/ETCCDI/. The trend change is considered significant if the estimated $p \leq 95 \%$.

Table 4. List of ETCCDI indices used to analyze climate extremes

\begin{tabular}{|c|c|c|c|}
\hline ID & Indicator & Definitions & Units \\
\hline \multicolumn{4}{|c|}{ Temperature } \\
\hline $\mathrm{TXx}$ & Max Tmax & $\begin{array}{l}\text { Monthly maximum value of daily maximum } \\
\text { temperature }\end{array}$ & ${ }^{\circ} \mathrm{C}$ \\
\hline $\mathrm{TNx}$ & Max Tmin & $\begin{array}{l}\text { Monthly maximum value of daily minimum } \\
\text { temperature }\end{array}$ & ${ }^{\circ} \mathrm{C}$ \\
\hline TXn & Min Tmax & $\begin{array}{l}\text { Monthly minimum value of daily maximum } \\
\text { temperature }\end{array}$ & ${ }^{\circ} \mathrm{C}$ \\
\hline $\mathrm{TNn}$ & Min Tmin & $\begin{array}{l}\text { Monthly minimum value of daily minimum } \\
\text { temperature }\end{array}$ & ${ }^{\circ} \mathrm{C}$ \\
\hline TN90p & Warm nights & Percentage of day when $\mathrm{TN}>90^{\text {th }}$ percentile & $\%$ \\
\hline TX90p & Warm days & Percentage of day when $\mathrm{TX}>90^{\text {th }}$ percentile & $\%$ \\
\hline WSDI & $\begin{array}{l}\text { Warm spell duration } \\
\text { indicator }\end{array}$ & $\begin{array}{l}\text { Annual count of days with at least } 6 \text { consecutive } \\
\text { days when } T X>90^{\text {th }} \text { percentile }\end{array}$ & days \\
\hline
\end{tabular}




\begin{tabular}{|c|c|c|c|}
\hline DTR & $\begin{array}{l}\text { Diurnal temperature } \\
\text { range }\end{array}$ & Monthly mean difference TX and TN & ${ }^{\circ} \mathrm{C}$ \\
\hline \multicolumn{4}{|c|}{ Precipitation } \\
\hline SDII & $\begin{array}{l}\text { Simple daily } \\
\text { intensity index }\end{array}$ & $\begin{array}{l}\text { Annual total precipitation divided by the number } \\
\text { of wet day (defined as PRCP }>=1.0 \mathrm{~mm} \text { ) in the } \\
\text { year }\end{array}$ & $\begin{array}{l}\mathrm{mm} / \mathrm{da} \\
\mathrm{y}\end{array}$ \\
\hline R10 & $\begin{array}{l}\text { Number of heavy } \\
\text { precipitation days }\end{array}$ & Annual count of day when $P R C P>=10 \mathrm{~mm}$ & days \\
\hline R25 & $\begin{array}{l}\text { Number of days } \\
\text { above } 25 \mathrm{~mm}\end{array}$ & Annual count of day when $P R C P>=25 \mathrm{~mm}$ & days \\
\hline CDD & Consecutive dry days & $\begin{array}{l}\text { Maximum number of consecutive days with } \\
\mathrm{RR}<1 \mathrm{~mm}\end{array}$ & days \\
\hline CWD & $\begin{array}{l}\text { Consecutive wet } \\
\text { days }\end{array}$ & $\begin{array}{l}\text { Maximum number of consecutive days with } \\
\mathrm{RR}>1 \mathrm{~mm}\end{array}$ & days \\
\hline R95P & Very wet days & Annual total PRCP when $\mathrm{RR}>95^{\text {th }}$ percentile & $\mathrm{mm}$ \\
\hline R99P & Extremely wet days & Annual total PRCP when RR $>99^{\text {th }}$ percentile & $\mathrm{mm}$ \\
\hline PRCPTOT & $\begin{array}{l}\text { Annual total wet day } \\
\text { precipitation }\end{array}$ & Annual total PRCP in wet days $(\mathrm{RR}>1 \mathrm{~mm})$ & $\mathrm{mm}$ \\
\hline
\end{tabular}

\section{Results}

\subsection{Annual and seasonal trend of hydroclimatic time series over MRB}

Results of applying MK statistical test on rainfall, mean temperature, PET, and discharge hydroclimatic average values of the whole MRB is showing in Table 5. On annual time scale, Athiémé, Corrokopé and Nangbéto discharge stations show none significant negative and positive trend respectively. The result of average values of rainfall and temperature over the study area reveals none significant negative trend of rainfall. However, a none positive trend of inflow and outflow of Nangbéto whereas $95 \%$ and $99 \%$ significance levels trend of mean temperature is noted.

At seasonal time scale (MAM, JJA, SON and DJF), the trend is detected in all hydroclimatic variables and particular the mean temperature is increasing at $95 \%$ and $99 \%$ significant level while a none positive trend of inflow and outflow at Nangbéto and negative trend of rainfall for the four seasons.

During MAM period, none negative significant trends on PET is observed. In opposite, Athiéme and Corrokope discharge stations, exposed a none positive significant. A similar situation is observed during JJA and SON seasons. Indeed, discharge at Athiéme was decreased at $95 \%$ significant levels during JJA and SON and increased during DJF. Afterward, the period in JJA period, appears a positive trend of PET and negative trend of discharge at Athiémé and Corrokopé. Further, none significant negative trend of PET and discharge (Athiémé and Corrokopé) is computed. Appendix shows the annual times series of precipitation, temperature, discharge and PET over the whole MRB. There is a positive annual trend of PET and mean temperature from 1961 to 2015 while negative trend of cumulative discharge at Athiémé (1961-2011) and of annual rainfall (1961-2015) with a breakpoint at the year of 1987.

Table 5. Results of statistical tests for seasonal and annual hydroclimatic variables in MRB 


\begin{tabular}{|c|c|c|c|c|c|c|c|c|}
\hline & & PET & Rainfall & Temperature & Q Athieme & Q corrokope & Inflow & Outflow \\
\hline $\mathrm{n}$ & & 36 & 36 & 56 & 50 & 38 & 24 & 24 \\
\hline \multirow{3}{*}{ MAM } & Zs & -0.04 & -0.91 & 6.47 & 1.63 & 0.72 & 1.02 & 1.07 \\
\hline & Sig & & & $* * *$ & & & & \\
\hline & Qmed & -0.21 & -1.43 & 0.030 & 4.578 & 0.149 & 4.06 & 20.66 \\
\hline \multirow{3}{*}{ JJA } & Zs & 0.86 & -0.81 & 7.61 & -2.37 & -0.53 & 0.17 & 0.02 \\
\hline & Sig & & & $* * *$ & $*$ & & & \\
\hline & Qmed & 0.19 & -2.68 & 0.028 & -61.008 & -15.075 & 15.27 & 2.52 \\
\hline \multirow{3}{*}{ SON } & $\mathrm{Zs}$ & -0.48 & -0.11 & 8.01 & -2.01 & -1.03 & 0.82 & 0.47 \\
\hline & Sig & & & $* * *$ & * & & & \\
\hline & Qmed & \begin{tabular}{|l|}
-0.049 \\
\end{tabular} & -0.16 & 0.031 & -92.319 & -33.965 & 79.25 & 57.65 \\
\hline \multirow{3}{*}{ DJF } & $\mathrm{Zs}$ & 4.02 & -0.20 & 7.47 & 3.66 & -0.78 & 1.20 & 3.25 \\
\hline & Sig & $* * *$ & & $* * *$ & $* * *$ & & & $* *$ \\
\hline & Qmed & 0.72 & -0.14 & 0.036 & 23.559 & -0.184 & 2.00 & 44.13 \\
\hline \multirow{3}{*}{ ANNUAI } & Zs & 1.78 & -0.52 & 8.38 & -1.65 & -1.03 & 0.57 & 0.97 \\
\hline & Sig & + & & $* * *$ & + & & & \\
\hline & Qmed & 0.83 & -2.23 & 0.031 & -26.267 & -12.643 & 22.37 & 33.15 \\
\hline
\end{tabular}

Zs: Mann-Kendall test, Qmed: Sen's slope estimator, Sig: significant indicator, - delineate negative trends based to the MK test, $n=$ length of the time series

$*$ Statistically significant trend at $\alpha=95 \%$ significance level

** Statistically significant trend at $\alpha=99 \%$ significance level

\subsection{Annual and seasonal trend at individual stations of climatic variables}

3.4.1. Mean temperature (TMP) and potential evapotranspiration (PET)

MK statistic trend applied for the mean temperature in individual station (Tabligbo, Atakpamé and Sokodé) over the period of 1961-2016 is summarized in Table 6. Consequently, at Tabligbo, Atakpamé and Sokodé stations, positive significant trend at $95 \%$ and $99 \%$ significant levels of mean temperature variable at seasonal and annual period time scale is observed.

Table 6. Results of Statistical tests for seasonal and annual

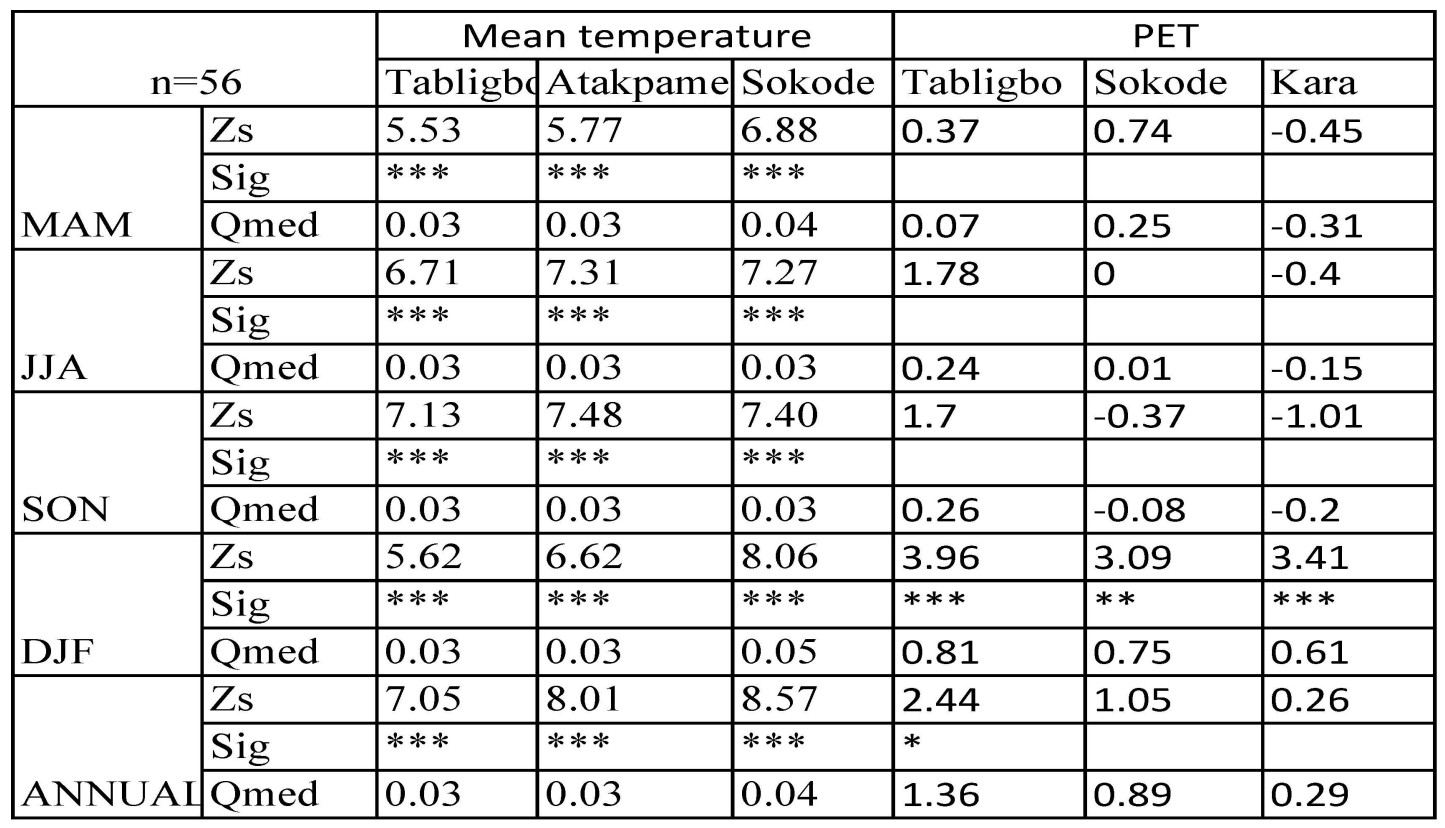

Zs: Mann-Kendall test, Qmed: Sen's slope estimator, Sig: significant indicator 
*Statistically significant trend at $\alpha=95 \%$ significance level

$* *$ Statistically significant trend at $\alpha=99 \%$ significance level

In the case of PET, the result is too similar considering the whole basin. However, during MAM a negative (Kara) and positive (Sokode and Tabligbo) trends are discovered but not significant. In the season of JJA at Kara the trend is negative and Tabligbo displayed positive trend and Sokodé no trend. During DJF the trends are positives in all the three stations at 95\% or/and 99\% significant level. For annual period, the trend is all positive with no significance except at Tabligbo where the significant trend is at $95 \%$ level.

\subsubsection{Rainfall stations over Mono river basin trend analysis result}

The results of rainfall stations trend analysis over MRB are displayed in Table 7.

Table 7. Annual and seasonal trend statistic of rainfall selected stations.

\begin{tabular}{|c|c|c|c|c|c|c|c|c|c|c|c|c|c|c|c|c|}
\hline & \multicolumn{3}{|c|}{ MAM } & \multicolumn{3}{|c|}{ JJA } & \multicolumn{3}{|c|}{$\mathrm{SON}$} & \multicolumn{3}{|c|}{ DJF } & \multicolumn{3}{|c|}{ ANNUAL } \\
\hline 1 & $n=56$ & Zs & Sig & Qmed & Zs & Sig & Qmed & $\mathrm{Zs}$ & Sig & Qmed & $\mathrm{Zs}$ & Sig & Qmed & $\mathrm{Zs}$ & Sig & Qmed \\
\hline & Kara & -1.05 & & -0.76 & -0.93 & & -1.05 & 1.24 & & 1.17 & 0.82 & & 0 & -0.08 & & -0.204 \\
\hline 2 & Kpewa & -1.24 & & -0.95 & -2.01 & & -2.54 & -2.47 & & -2.7 & 1.37 & & 0.1 & -2.72 & & -6.9 \\
\hline 3 & Tchamba & -1.09 & & -1.68 & -0.04 & & -0.03 & -0.46 & & 0 & -1.44 & & -0.21 & -0.93 & & -0.755 \\
\hline 4 & Sokode & -0.88 & & -1.18 & -0.36 & & -0.08 & -0.55 & & 0 & -1.16 & & -0.34 & -2.21 & & -1.183 \\
\hline 5 & Malfacassa & -1.78 & & -1.72 & -2.10 & & -3.04 & 1.18 & & 0.067 & -2.13 & & -0.41 & 1.78 & & 1.304 \\
\hline 6 & Bassila & -1.04 & & -1.58 & -1.19 & & -1.34 & 0.87 & & 0.14 & -1.06 & * & -0.35 & -1.08 & & -0.95 \\
\hline 7 & Sotouboua & 0.32 & * & 0.70 & 0.20 & & 0.51 & 0.62 & & 0.029 & -0.09 & & -0.011 & -0.4 & & -0.37 \\
\hline 8 & Blitta & -0.94 & * & -0.45 & 0.25 & & 0.23 & 1.26 & & 0.17 & -0.06 & * & -0.042 & 0.59 & & 0.38 \\
\hline 9 & Yegue & -0.38 & & 0.00 & -0.22 & * & 0.00 & -0.18 & & 0 & -0.13 & * & -0.063 & 0.41 & & -0.33 \\
\hline 10 & Akaba & 1.35 & & 1.2 & 1.31 & * & 4.07 & 0.28 & & 0.011 & 1.92 & & 0.53 & 1.15 & & 0.78 \\
\hline 11 & Tchetti & -1.13 & & -0.762 & -0.2 & & -0.346 & 0.31 & & 0.39 & -1.14 & & -0.229 & -0.54 & & -1.207 \\
\hline 12 & Anie & 0.11 & & 0.19 & 1.36 & & 1.85 & -0.04 & & 0 & 0.95 & & 0.19 & -0.7 & & -0.8 \\
\hline 13 & Agouna & 0.19 & & 0.272 & 2.54 & & 2.25 & -1.05 & & \begin{tabular}{|l|}
-0.189 \\
\end{tabular} & 1.39 & & 0.364 & 1.16 & & 0.98 \\
\hline 14 & Atakpame & -0.28 & & -0.42 & 1.17 & & 0.86 & -1.12 & & -0.32 & 0 & & 0 & 1.11 & & 1.04 \\
\hline 15 & Amou & -0.7 & & -0.8 & 0.11 & & 0.194 & 1.36 & & 1.85 & -0.04 & & 0 & 1.27 & & 3.107 \\
\hline 16 & Wahala & -1.17 & & -1.084 & 0.233 & & 0.377 & -0.96 & & -0.65 & -0.899 & & -0.31 & -0.5725 & & -1.133 \\
\hline 17 & Lonkly & 1.63 & & 2.95 & 1.6 & & 1.31 & -1.77 & & -0.5 & 1.04 & & 0.25 & -0.18 & & -0.17 \\
\hline 18 & Notse & -0.87 & & -0.97 & 2.49 & & 3.27 & 1.15 & * & 1.47 & -2.11 & & -0.75 & 1.07 & & 3.52 \\
\hline 19 & Adjarala & -1.07 & & -1.39 & -1.89 & & -2.3 & 0.01 & & 0 & -2.24 & & -0.4 & -1.37 & & -0.78 \\
\hline 20 & Tabligbo & -0.8 & & -0.6 & 0.25 & & 0.2 & 1.55 & & 1.39 & -0.61 & & -1.68 & 0.42 & & 0.851 \\
\hline 21 & Afanyangan & 0.19 & & 0.27 & 2.54 & & 2.25 & -1.05 & & -0.18 & 1.39 & * & 0.36 & 1.16 & & 0.98 \\
\hline
\end{tabular}

Zs: Mann-Kendall test, Qmed: Sen's slope estimator, Sig: significant indicator, - delineate negative trends based to the MK test

*Statistically significant trend at $\alpha=95 \%$ significance level

The seasonal and annual MK test analysis where performed at each rainfall gauge stations that were used to compute the mean rainfall over the entire basin and results are shown in Table 7 . The analysis reveals that, 6 out of 21 stations present positive trend and the rest negative trend in MAM, 12 out of 21 stations in JJA positive and 9 negative trends, at SON there are 10 stations with positive trend and 11 with negative trend while during the period of DJF only 7 stations have positive trend, 13 negative trend and one displays no trend over MRB.

According to Table 7 results, positive or negative and not significant trends are displayed for annual rainfall in each station. On seasonal scale, there are positive trend at Sotouboua and negative trend at Blitta at 95\% significance level in MAM. Positive and negative trend are also detected respectively at Akaba and Yegue stations in JJA at 95\% significant level. During SON, Notse is the only station where there is positive trend at $95 \%$ significant level while in the others stations the trend is not significant. In DJF, a decreasing trend at 95\% significant level is detected at the stations of Bassila, Blitta and Yegue. 
3.4.3. Spatial distribution at seasonal and annual time scale of rainfall

The spatial trend distribution of rainfall, discharge and temperature are showed in Figure 2

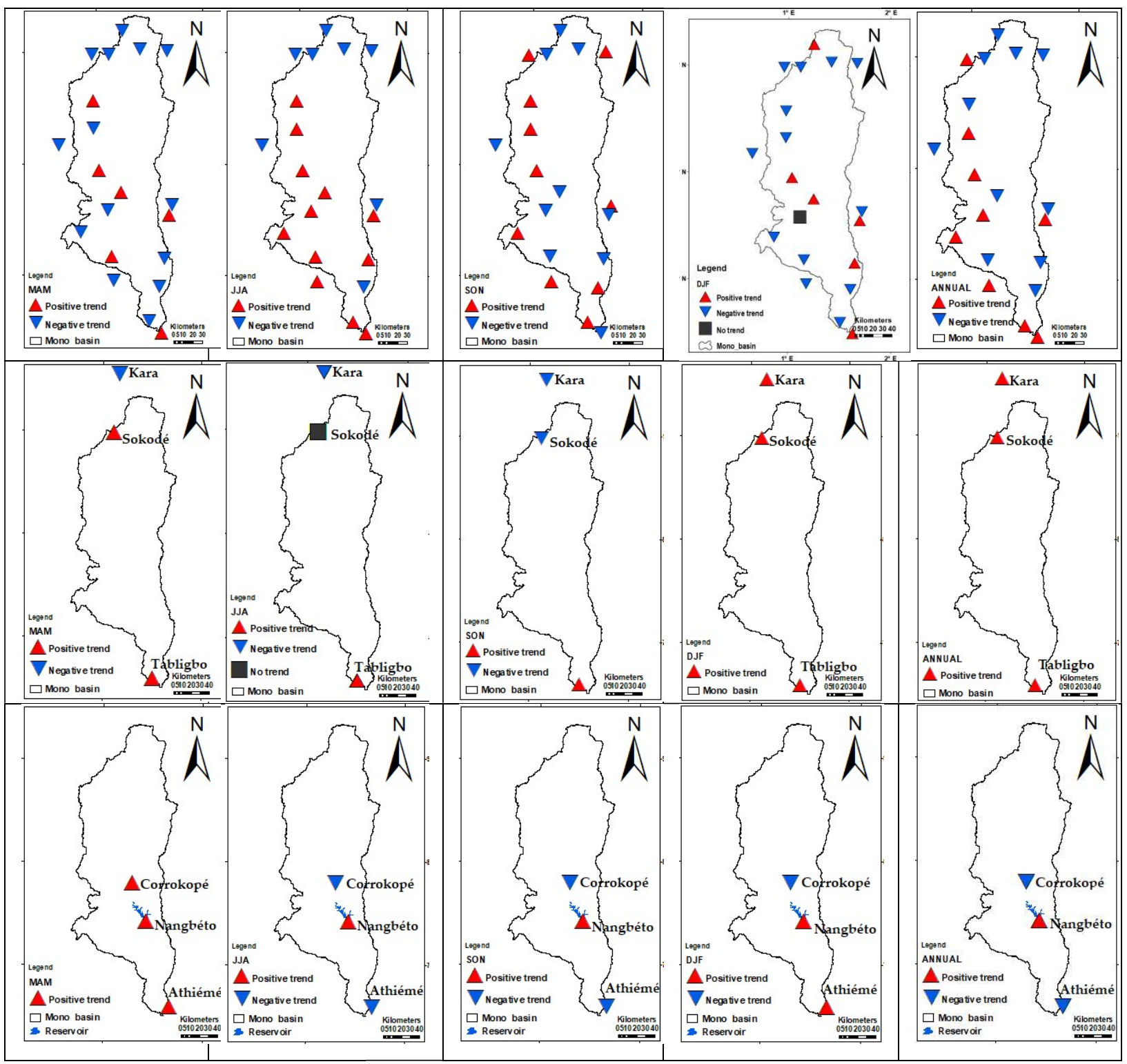

Figure 2. The spatial distribution of rainfall (top), PET (middle) and discharge (bottom)

The spatial distribution of rainfall from 21 stations over the MRB displayed in Figure 2 shows positive, no and negative trend during the seasonal and annual period between 1961 -2016. At annual period, nine of twenty-one station show an increase trend of rainfall and the rest one a decrease. All the stations with increase rainfall are in the West from North to South. These are area are in the high slope of mountain except Tchetti station in the East where it can be explained by others factors. The similar situations are observed during JJA and SON with some exceptions. During MAM and DJF seasons 6 stations are with positive trends of rainfall. In Figure 2, during MAM all the hydrological stations show an increase of discharge while in JJA and SON there are two stations of decrease over three. Only at Nangbéto the discharge is increasing because it is the rainy season. During the period of DJF and at annual scale the upstream stations of Corrokopé has an decrease of discharge while at Nangbéto there is, increase during DJF at the outlet and decrease at annual time scale. 
At the downstream, the PET is increasing during all seasonal and annual periods. In the upstream of the basin the station outside of the river show a decrease trend during MAM, JJA and SON while increase during DJF and annual time scale. The stations being outside PET is link with the river hydrology because of land -atmosphere exchange. Finally, the second stations at the upstream show a positive trend for MAM, DJF and annual while no trend is detected during JJA and negative trend in SON.

\subsection{Multi-ensemble model temporal validation of mean temperature (1980-2005)}

Table 8 shows the coefficient of determination and bias between ensemble model and observations time series at three major stations of mean temperature. There is an excellent coefficient of determination $\left(R^{2}>0.95\right)$ between model and observation at each station. The bias is less than $\pm 25 \%$ in the three stations at monthly and annually scale even equal to zero in November at Tabligbo station. The ensemble model slightly underestimates the observations with a small positive deviation as given in Figure 3 and confirmed the low bias values.

There is good trend regression at Tabligbo (0.96), Atakpamé (0.98) and Sokodé (0.97) coefficient of regression between the model outputs and observations. At seasonal variability between 1980 and 2005, we can see that the seasonality is well represented in the stations. We concluded that the model outputs are much representing observation data in the MRB

Table 8. Determination coefficient, bias values for mean temperature (1980-2005).

\begin{tabular}{|l|c|c|c|c|c|c|c|c|c|c|c|c|c|r|}
\hline Bias [\%] & $\mathbf{R}^{\mathbf{2}}$ & Jan & Feb & Mar & Apr & May & Jun & Jul & Aug & Sep & Oct & Nov & Dec & Annual \\
\hline Tabligbo & 0.96 & 1.30 & 2.60 & 2.18 & 1.36 & 0.94 & 0.61 & 2.20 & 1.28 & 1.05 & 0.50 & 0.00 & -0.15 & 1.16 \\
\hline Atakpamé & 0.98 & 3.06 & 3.96 & 3.71 & 4.54 & 4.67 & 5.07 & 5.63 & 5.62 & 5.71 & 4.61 & 3.19 & 3.12 & 4.41 \\
\hline Sokodé & 0.97 & 4.72 & 3.15 & 0.98 & 1.65 & 3.13 & 3.78 & 4.62 & 5.24 & 4.70 & 3.27 & 3.48 & 5.14 & 3.66 \\
\hline
\end{tabular}

The bias or error between model and observation are too low and range between $-0.15 \%$ and $6 \%$ at Sokodé, Atakpamé and Tabligbo stations at annual scale between 1980 and 2005.

\subsection{Multi ensemble model temporal and spatial validation of rainfall (1980-2005)}

3.6.1. Time series comparison

The validation of rainfall over MRB was performed using 21 gauge stations. Figure 4 and Table 8 are showing the bias between the ensemble model outputs and observations. The coefficient of determination between model and observation is displayed in Table 9 and is showing a very good correlation between the two datasets. The bias computed as the ratio over observations of the difference of model value to observation. There is high bias at Tchamba and Adjarala stations in July, August and September. The bias in the others stations are quite acceptable. In detail Table 9 show the monthly bias per station. The model underestimates the observation globally in these stations (Figure 3 \& Figure 4).

From the Table 9 there are some stations with high bias (bias value $\geq \pm 25 \%$ ) globally at $12 \%$ of 252 grids evaluated. Particulary, highest bias is observed at Sotouboua, Yegue, Tchetti, Anié, Agouna, Lonkly and Afanyangan.

The very highest bias is observed at Yegue in November (71.8\%). For the other station value never exceed $\pm 25 \%$. However the months of March, June and July bias are all lower than $\pm 25 \%$. Globally at annually the bias are acceptable for the 21 stations. The highest bias obtained can be due to downscaling methods. 


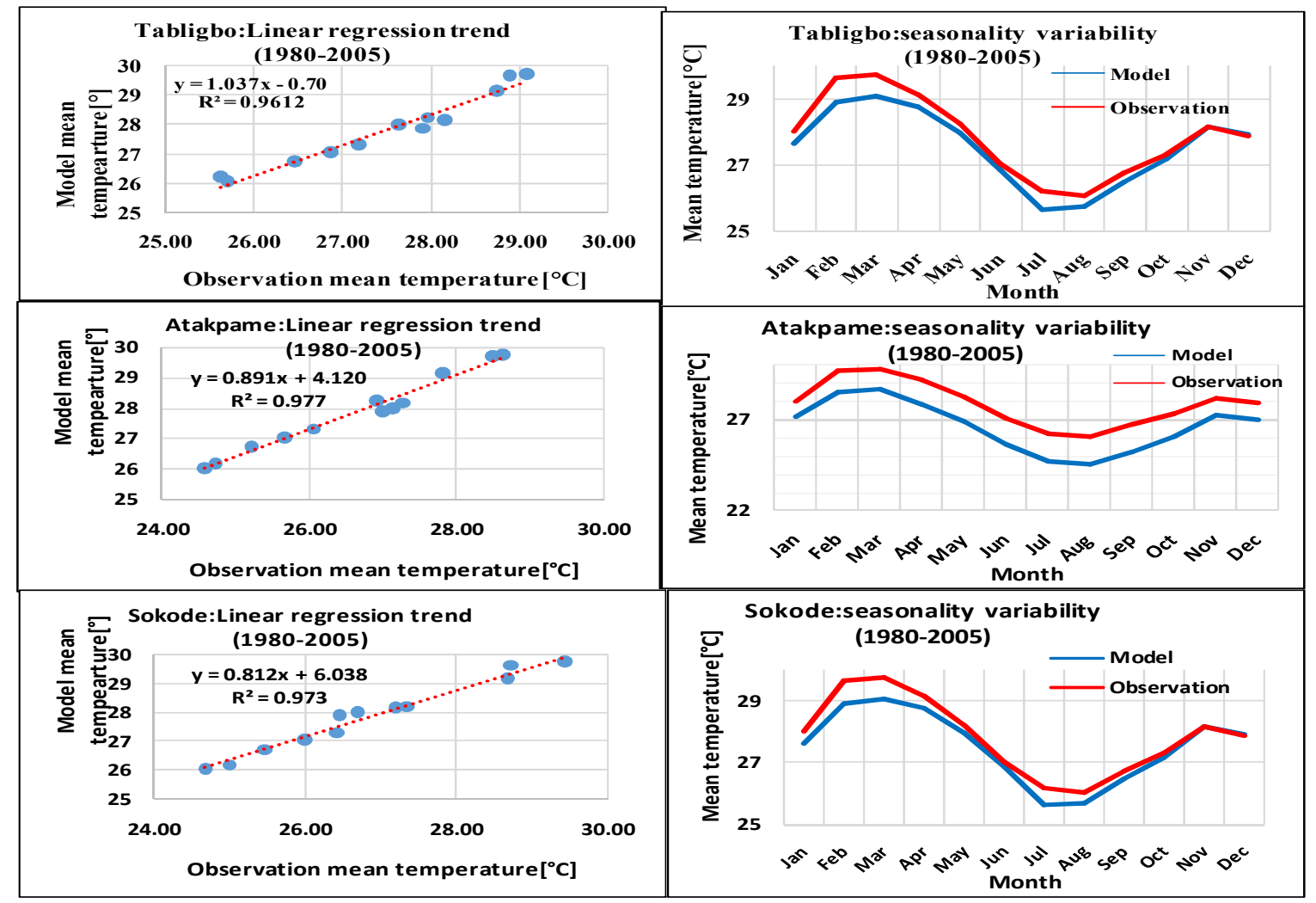

Figure 3. Observed and model mean temperature time series comparison

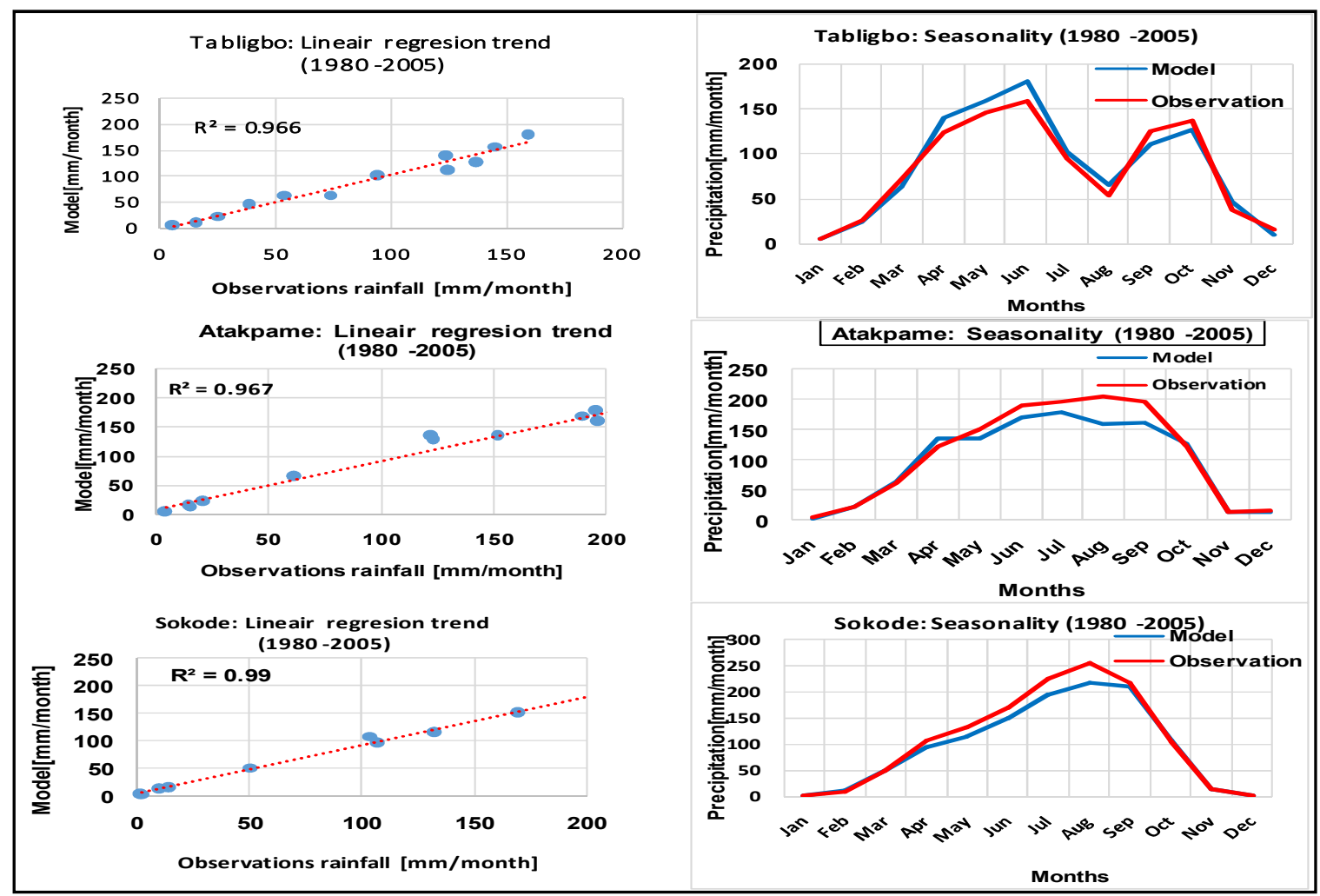

Figure 4. Observed and ensemble model precipitation time series comparison

Table 9. Bias [\%] between climate model rainfall and observations 


\begin{tabular}{|c|c|c|c|c|c|c|c|c|c|c|c|c|c|c|c|}
\hline \multicolumn{16}{|c|}{ Annual and monyhly bias betweem ensemble model and observations (1980-2005) } \\
\hline No & Station & $R^{2}$ & Jan & Feb & Mar & Apr & May & Jun & Jul & Aug & Sep & Oct & Nov & Dec & Annual \\
\hline 1 & Kara & 0.993 & 19.6 & -5.8 & 2.1 & 8.5 & 15.6 & 14.8 & 2.5 & 2.5 & 10.5 & 7.8 & 0.7 & 16.0 & 7.9 \\
\hline 2 & Kpewa & 1.00 & 11.1 & -25.0 & 20.7 & 4.7 & 21.4 & 17.8 & 14.0 & 12.5 & 9.1 & 10.7 & 24.6 & 17.6 & 11.6 \\
\hline 3 & Tchamba & 97 & -10.0 & 1.0 & -19.3 & 12.1 & -13.1 & -6.0 & 21.1 & 9.9 & 4.9 & 1.8 & 15.5 & 15.7 & 2.8 \\
\hline 4 & Sokode & 0.97 & -17.0 & -2.1 & -10.5 & 11.0 & 25.4 & 24.4 & 1.3 & -1.7 & 4.1 & -10.9 & -33.1 & -7.8 & -1.4 \\
\hline 5 & Malfacassa & 0.91 & 27.8 & -1.6 & -7.6 & -27.8 & -31.9 & -21.5 & 19.0 & 20.4 & 4.1 & 3.1 & 20.8 & 2.8 & 0.6 \\
\hline 6 & Bassila & 0.99 & -0.9 & 0.3 & 11.1 & -0.4 & -3.3 & -18.1 & 4.4 & -13.5 & -4.2 & 8.4 & -11.2 & 17.3 & -0.8 \\
\hline 7 & Soto & 99 & 3.4 & -10.0 & 8.9 & 14.0 & 17.8 & 7.0 & 13.5 & 1.6 & -9.4 & -4.7 & 61.9 & 0.1 & 8.7 \\
\hline 8 & Blitta & 0.96 & -12.2 & -18.3 & -24.6 & 1.4 & 3.6 & -4.8 & -0.2 & 13.3 & 25.5 & 14.3 & 11.0 & 0.0 & 0.8 \\
\hline 9 & Yegue & 0.96 & 19.3 & 25.6 & -10.8 & 6.7 & 6.1 & 10.7 & -13.9 & 9.7 & 10.3 & 25.7 & 71.8 & 42.6 & 17.0 \\
\hline 10 & Akaba & 0.98 & -1.7 & -4.1 & 17.6 & -2.5 & -14.6 & 8.8 & 3.9 & 13.8 & 3.8 & -4.8 & -7.4 & -9.0 & 0.3 \\
\hline 11 & Tchetti & 0.97 & 1.6 & -14.0 & -9.9 & 4.2 & 12.5 & 16.7 & 14.4 & 24.3 & 2.6 & -41.2 & 13.4 & 0.1 & 2.0 \\
\hline 12 & Anie & 0.97 & -50.0 & -6.4 & 3.0 & -10.5 & 1.1 & 9.6 & -1.1 & 14.1 & -0.7 & -28.3 & -13.1 & 30.8 & -4.3 \\
\hline 13 & Agouna & 0.99 & -6.2 & 18.3 & 8.7 & 0.1 & -4.2 & 8.3 & 11.5 & 12.7 & 4.6 & 6.7 & -41.3 & -18.1 & 0.1 \\
\hline 14 & Atakpame & 0.96 & -25.3 & -1.2 & -20.8 & 7.2 & 18.4 & 15.9 & -8.9 & 5.1 & 17.2 & -10.9 & -0.3 & 17.3 & 1.1 \\
\hline 15 & Amou & 0.99 & 19.6 & 28.8 & 20.9 & 13.1 & 4.2 & 11.9 & 10.6 & 18.3 & 18.5 & 2.1 & -3.5 & -2.6 & 11.8 \\
\hline 16 & Wahala & 0.91 & 24.7 & -16.3 & -10.8 & 0.1 & -29.1 & -21.1 & 19.8 & 9.9 & 14.8 & 6.1 & 23.5 & -7.4 & 1.2 \\
\hline 17 & Lonkly & 0.97 & 3.8 & 0.9 & 0.4 & 18.0 & -8.4 & -5.6 & -3.8 & 10.2 & 5.8 & -0.1 & -6.1 & 65.5 & 6.7 \\
\hline 18 & Notse & 0.89 & 29.3 & 5.3 & 0.1 & -18.4 & -29.5 & -5.5 & 19.6 & 19.3 & 19.5 & -7.6 & -4.6 & 29.8 & 4.8 \\
\hline 19 & Adjarala & 0.96 & -9.4 & -3.7 & 0.4 & -21.4 & 6.1 & 22.8 & -0.8 & 21.3 & -1.9 & 8.2 & 11.7 & -1.2 & 2.7 \\
\hline 20 & Tabligbo & 0.96 & 2.7 & -5.2 & 14.2 & -14.3 & -6.3 & -4.6 & -23.8 & -1.7 & 6.8 & 9.7 & -0.1 & 18.6 & -0.3 \\
\hline 21 & Afanyangan & 0.92 & -65.1 & -6.8 & -17.1 & -47.4 & -44.6 & -18.5 & -24.8 & -32.6 & 11.1 & -12.1 & -43.9 & -5.7 & -25.6 \\
\hline
\end{tabular}

Note: High value of bias (bias $\geq \pm 25 \%$ ) in bolt

\subsubsection{Spatial representation of rainfall of climate model and obseravtions}

In order to determine the difference between ensemble model and observation, spatial interpolation representation of rainfall in DJF and JJA are computed in Figure 5. DJF months represents the dry seasons and the rainy season in JJA when the rainfall is at the maximum. In DJF, the model and observation show high values of rainfall are in the southwest of the basin $(16.8 \mathrm{~mm} / \mathrm{month}$ and 16.6 $\mathrm{mm} / \mathrm{month}$ respectively). The low values of rainfall are in the north such as in the model (7 $\mathrm{mm} / \mathrm{month})$ and in observations $(10.3 \mathrm{~mm} / \mathrm{month})$.However model shows in the southeast a low value of rainfall. As the model, observations mean values of rainfall are seen in the center of the MRB.

The maximum values of rainfall in the model $(196.7 \mathrm{~mm} / \mathrm{month})$ and observations $(215.98 \mathrm{~mm} / \mathrm{month})$ during JJA period are located in the Northwest of MRB. The low values of rainfall during this period are situated in the south of the basin for the two datasets.

The coefficient of correlation between observations and ensemble model are 0.62 and 0.82 respectively in DJF and JJA which are acceptable. However the extremes value from the model and observation are closer in DJF and JJA. The rainfall variability (seasonality) such as in the model and observations is accurate. It is exactly predicted by the model in the south (Tabligbo) two peaks of maximum rainfall in June and October and in the center and north (Atakpamé and Sokodé) one peak of maximum rainfall in August reflecting the two different climate zone cover by MRB as displayed the time series in section 3.6.1. 


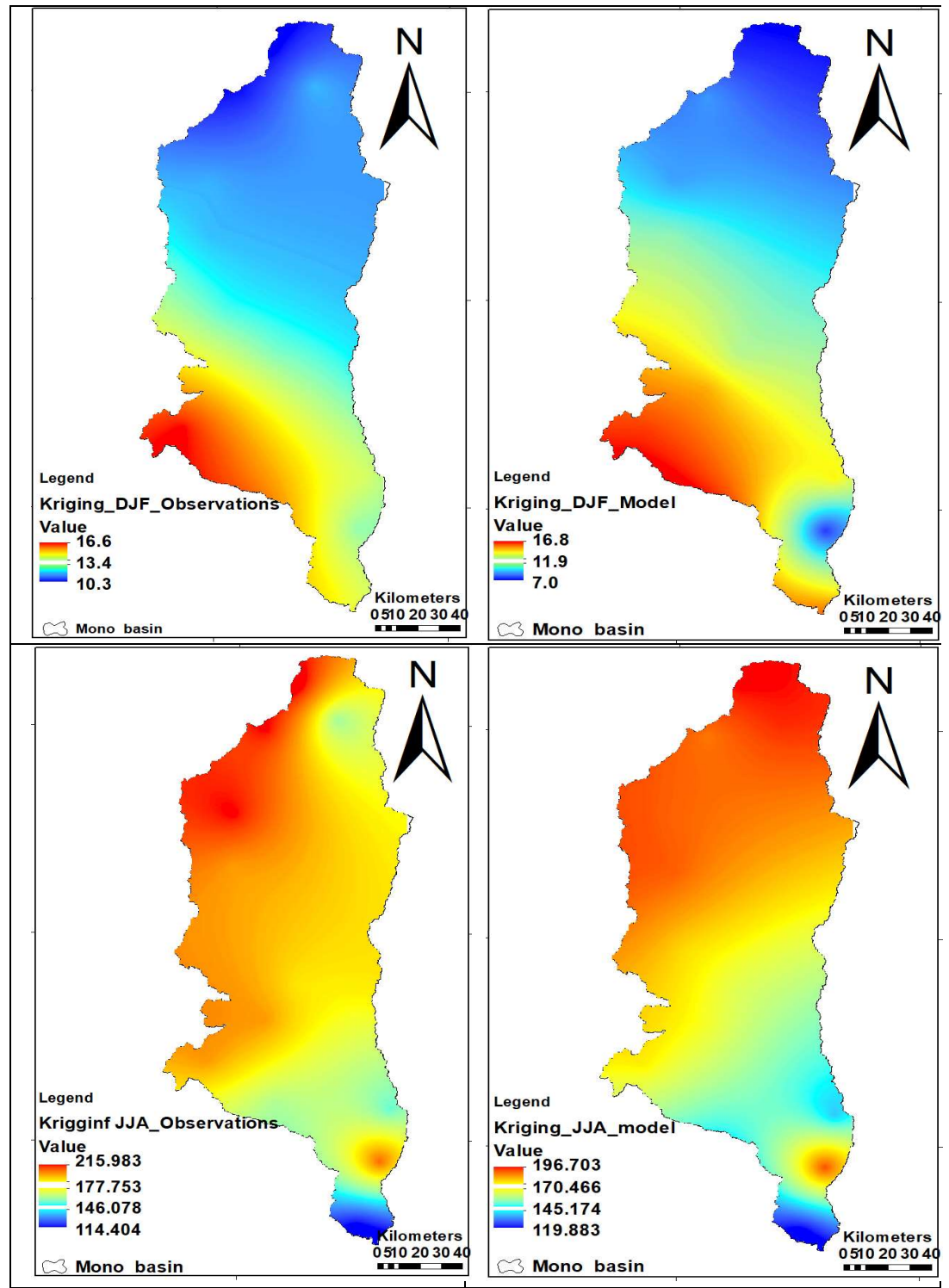

Figure 5. Spatial distribution of rainfall (mm/month) of climate model and observations

\subsection{Future scenarios temperature and precipitations extreme indices}

The trend analysis results for RCP4.5 and RCP8.5 in three major climatic stations of MRB are summarized in Table 10. The values in bold indicate the significant trend at $95 \%$ confidence level. The results show at annual scale that the significant negative, positive or no trend will be observed at some station from 2020 to 2045 and depending of the scenarios and the selected extremes indices. The monthly maximum value of daily temperature indices (TNn), and rainfall indices such as simple daily index (SDII) number of heavy precipitation days (R10), number of days above $25 \mathrm{~mm}$ of precipitation (R25) and consecutive dry days (CDD) don't present significant trend in the three station but with positive or negative slope reflecting increase or decrease of annual rainfall in RCP4.5 or RCP8.5. Rainfall intensity indices like annual precipitation amount (PRCPTOT) show no significant increase (decrease) trend at Sokodé of $6.014 \mathrm{~mm} /$ year $(5.269 \mathrm{~mm} /$ year) of RCP4.5 (RCP8.5) respectively, positive trend of $5.635 \mathrm{~mm} /$ year of RCP4.5 and $6.159 \mathrm{~mm} /$ year of RCP8.5 at Atakpamé while $5.469 \mathrm{~mm} /$ year of RCP4.5 and $5.975 \mathrm{~mm} /$ year of RCP8.5 at Tabligbo. These results show an increase of rainfall at two selected stations of MRB.

Table 10. Annual extremes indices of temperature and precipitation for RCP4.5 and RCP8.5 (2020 to 2045) 


\begin{tabular}{|c|c|c|c|c|c|c|c|c|c|c|c|c|c|c|c|c|c|c|}
\hline \multirow{4}{*}{$\begin{array}{l}\text { Zone } \\
\text { Indices }\end{array}$} & \multicolumn{6}{|c|}{ North of the basin } & \multicolumn{6}{|c|}{ Center of the basin } & \multicolumn{6}{|c|}{ South of the basin } \\
\hline & \multicolumn{6}{|c|}{ Sokode } & \multicolumn{6}{|c|}{ Atakpame } & \multicolumn{6}{|c|}{ Tabligbo } \\
\hline & \multicolumn{2}{|c|}{ Slope } & \multicolumn{2}{|c|}{ Sen of slope } & \multicolumn{2}{|c|}{$p$ value } & \multicolumn{2}{|c|}{ Slope } & \multicolumn{2}{|c|}{ Sen of slope } & \multicolumn{2}{|c|}{$p$ value } & \multicolumn{2}{|c|}{ Slope } & \multicolumn{2}{|c|}{ Sen of slope } & \multicolumn{2}{|c|}{$p$ value } \\
\hline & RCP4.5 & RCP8.5 & RCP4.5 & RCP 8.5 & RCP4.5 & RCP8.5 & RCP4.5 & RCP8. & RCP4.5 & RCP 8.5 & RCP4.5 & RCP8.5 & RCP4.5 & RCP8.5 & RCP4.5 & RCP8.5 & RCP4.5 & RCP8.5 \\
\hline TXx & -0.021 & 0.078 & 0.03 & 0.034 & 0.502 & 0.03 & 0.105 & 0.133 & 0.033 & 0.061 & 0.004 & 0.040 & -0.023 & 0.102 & 0.04 & 0.039 & 0.575 & 0.015 \\
\hline TNx & 018 & 0.073 & 0.015 & 0.015 & 0.228 & 0.000 & 0.005 & 0.065 & 0.011 & 0.016 & 0.676 & 0.00 & 0.043 & 0.075 & 0.009 & 0.011 & 0.00 & 0.00 \\
\hline TXn & -0.005 & 0.045 & 0.012 & 0.015 & 0.686 & 0.007 & 0.001 & 0.057 & 0.01 & 0.016 & 0.925 & 0.002 & 0.014 & 0.037 & 0.01 & 0.009 & 0.16 & 0.001 \\
\hline TNn & 0.002 & 0.005 & 0.023 & 0.025 & 0.943 & 0.855 & 0.01 & 0.02 & 0.02 & 0.022 & 0.619 & 0.371 & 0.024 & 0.009 & 0.035 & 0.035 & 0.488 & 0.805 \\
\hline TX90p & -0.116 & 0.359 & 0.075 & 0.091 & 0.135 & 0.001 & 0.374 & 0.399 & 0.163 & 0.297 & 0.031 & 0.192 & -0.05 & 0.724 & 0.186 & 0.115 & 0.79 & 0.00 \\
\hline TN90p & 0.312 & 0.741 & 0.069 & 0.09 & 0.000 & 0.00 & 0.417 & 0.813 & 0.09 & 0.103 & 0.00 & 0.00 & 0.446 & 1.128 & 0.073 & 0.12 & 0.00 & 0.00 \\
\hline ISDI & -0.086 & 0.163 & 0.065 & 0.082 & 0.196 & 0.058 & 0.301 & 0.504 & 0.298 & 0.568 & 0.323 & 0.384 & -0.09 & 0.618 & 0.325 & 0.158 & 0.785 & 0.001 \\
\hline DTR & -0.025 & -0.008 & 0.008 & 0.01 & 0.006 & 0.409 & 0.015 & 0.023 & 0.013 & 0.026 & 0.271 & 0.376 & -0.021 & 0.007 & 0.01 & 0.01 & 0.053 & 0.48 \\
\hline SDII & 0.026 & -0.05 & 0.049 & 0.054 & 0.598 & 0.358 & -0.016 & 0.061 & 0.05 & 0.068 & 0.746 & 0.38 & 0.057 & -0.018 & 0.057 & 0.054 & 0.321 & 0.737 \\
\hline R10 & 0.369 & -0.035 & 0.214 & 0.197 & 0.098 & 0.862 & 0.144 & -0.016 & 0.149 & 0.162 & 0.344 & 0.92 & 0.279 & 0.082 & 0.154 & 0.198 & 0.083 & 0.681 \\
\hline $\mathrm{R} 25$ & 0.122 & -0.046 & 0.107 & 0.104 & 0.263 & 0.659 & 0.109 & -0.041 & 0.1 & 0.09 & 0.286 & 0.65 & 0.072 & -0.061 & 0.103 & 0.097 & 0.494 & 0.538 \\
\hline CDD & 0.846 & 0.748 & 0.781 & 0.753 & 0.289 & 0.331 & 0.439 & 1.233 & 0.798 & 0.637 & 0.587 & 0.065 & -0.068 & 0.713 & 0.574 & 0.484 & 0.906 & 0.154 \\
\hline CWD & 0.138 & 0.061 & 0.056 & 0.049 & 0.02 & 0.226 & 0.121 & -0.087 & 0.039 & 0.039 & 0.005 & 0.034 & 0.09 & -0.023 & 0.058 & 0.041 & 0.132 & 0.582 \\
\hline R95p & 2.251 & -4.055 & 4.096 & 4.519 & 0.588 & 0.378 & -1.02 & 3.843 & 3.825 & 5.779 & 0.792 & 0.512 & 4.345 & 2.479 & 2.986 & 4.292 & 0.158 & 0.569 \\
\hline R99p & 1.721 & -0.766 & 2.431 & 2.634 & 0.486 & 0.774 & -1.674 & 4.875 & 2.33 & 3.666 & 0.48 & 0.196 & 5.24 & 1.798 & 2.367 & 2.677 & 0.037 & 0.508 \\
\hline ВСРТОТ & 10.638 & -1.632 & 6.014 & 5.269 & 0.09 & 0.759 & 3.341 & 1.433 & 5.635 & 6.159 & 0.559 & 0.818 & 9.327 & 4.182 & 5.469 & 5.975 & 0.101 & 0.491 \\
\hline
\end{tabular}

Note: Significant trends are in bold ( $p$ value $<95 \%$ ), negative slope shows a decreasing trend while positive shows an increasing trend.

The indices (R99p) increase significantly at Tabligbo for RCP8.5 whereas not significant at Atakpamé and Sokodé stations. The consecutive wet days (CWD) for RCP8.5 are significantly increasing at Sokodé and Atakpamé while not significant at Tabligbo. The maximum 5-day precipitation amount (RX5day) is only significant for RCP4.5 at Sokodé with a slope of $3.18 \mathrm{~mm}$.

The monthly maximum of daily maximum temperature (TXx), the monthly minimum of maximum temperature (TXn) and monthly maximum value of daily minimum temperature (TNx) for RCP8.5 show a significant trend in Sokodé, Atakpamé and Tabligbo representative stations respectively of $0.03{ }^{\circ} \mathrm{C}, 0.012^{\circ} \mathrm{C}$ and $0.015^{\circ} \mathrm{C}$ at Sokodé while $0.061^{\circ} \mathrm{C}, 0.016^{\circ} \mathrm{C}, 0.06^{\circ} \mathrm{C}$ at Atakpamé and $0.039^{\circ} \mathrm{C}$; $0.009^{\circ} \mathrm{C}$ and $0.011^{\circ} \mathrm{C}$ at Tabligbo.

The diurnal temperature (DTR) indices are only significant at Sokodé for RCP4.5 with positive slope showing the increase of monthly mean difference TX and TN. Temperature indices warm days (TX90p) show positive and negative trend at 95\% level of confidence for the Scenarios RCP8.5 in the north of the basin at Sokodé station, positive significant trend of RCP4.5 and RCP8.5 at Atakpamé station while at Tabligbo station in the south the significant trend is negative. This reveals that cool days and warm day annually trend depend from station and of RCP scenarios in MRB from 2020 to 2045. Nevertheless, warm nights (TN90p) are all showing significant trend at Tabligbo, Atakpamé and Sokodé at 95\% significant levels and for the two considered RCP4.5 and RCP8.5. A particularly TN10p slope is negative while positive for TN90p. The warm spell duration indicator (WSDI) shows only a significant RCP8.5 negative trend at Tabligbo.

\section{Discussions}

The temperatures historical trend analysis shows a significant upward of temperature over the whole basin and at individual temperature station which is in concordance with most of the previous 
studies investigated in this region [1]. The finding are similar to Lawin et al. [21,22] who reported a low and high increase of temperature over MRB from 1961-2010. A highest increase of temperature of $3^{\circ} \mathrm{C}$ around $14^{\circ} \mathrm{N}$ in May -June and low increase of $0.5^{\circ} \mathrm{C}$ below $8^{\circ} \mathrm{N}$ were also observed over West Africa [59-61]. Over the basin, negative significant trend of precipitation at annual and seasonal time scale whereas positive and negative significant trend are observed in PET at annual and seasonal may be linked with temperature increasing. During the last forty years, West African country have been experimented very driest periods with drought and extremes temperature which consequences have drastically impacted on local communities activities such as agriculture, water resource, biodiversity and economy $[18,36,62,63]$.

The ensemble Climate model underestimates observations from 1980 to 2005 with a accurate coefficient of determination higher than 0.9 in almost most of the climate stations over the basin. Therefore, uncertainties associated with model are minimized with rainfall percent bias less that \pm $25 \%$. The spatial coefficient of correlation between observations and model outputs is over 0.6 during the extremes values of rainfall (1980-2005). The ensemble model underestimation can be explained by weakness of primitives equation used during climate model generations which are not able to reproduce all the process of the earth what involves errors [64,65].

The finding of increase or decrease of PRCPTOT, SDII, CDD and R25 rainfall indices at the selected station or TXn, TXX, DTR and WSDI temperature indices confirmed most of the researches on climate trend analysis and extremes indices experimented in West Africa last year. Most of the results show the increase of extremes events like flooding and drought. West African countries are seen warm extremes temperature in the last year (1961-2000) with significant or not decreasing trend of rainfall [66]. For example Akinsanola and Zhou [67] used RCMs CORDEX to compute CDD, CWD, R10mm, R20mm, PRCPTOT, R95pTOT, RX5day, and SDII extreme rainfall indices under middle and high Representative Concentration Pathway (RCPs) scenarios RCP4.5 and RCP8.5 over West Africa. The results show a significant decrease of total rainfall, increase of consecutive dry and extreme events for the future period of 2070-2099. In Benin Yabi and Afouda [68] found an increase of rainfall and drought between 1922 to 2005 with a very dry period noticed between 1970s and 1980s. The study results therefore confirmed the rainfall variability and positive trend of mean temperature over MRB. In previous analysis using REMO model for historical period of 1980-2010 and RCP4.5 and RCP8.5 future emission scenarios (2018-2050), Lawin et al. [21] have showed over the entire watershed increase of rainfall and temperature for historical data and high variability of rainfall during the future scenarios. The same author preformed analysis using different regional climate model during the baseline of 1961-2010 and with high emission scenarios of RCP8.5 from 2051-2100 of temperature, and deduced high extremes trend of temperature between 1961-2010 and an increase of temperature during future change at almost in more station of the river with increase of extremes indices of TX90p, TX10p, TN90p and TN10p. Therefore, for any analysis performed a local scale, the result will be more applicable for decision makers and for local communities' information. In the case of MRB population growth have an essential impacts on land use and land cover changes as conclude by Koubodana et al. [30]. The same authors have showed that MRB is characterized by deforestation and savanna decrease and will continue to decrease in the 30 next years if nothing is done.

Also, since the major hydrological component such as rainfall, potential evapotranspiration/temperature are varying considerably in MRB, this have impacts on runoff at upstream-downstream station of the basin (Corrokopé and Athiémé). The results displayed over the basin and during the rainy period a considerable change. Thus in JJA and SON there is an increase of temperature, decrease of rainfall and increase (JJA), decrease (SON) of PET which are involving decrease of discharge at Corrokopé and Athiémé. 


\section{Conclusion}

This study contributes to the understanding of seasonal and annual hydroclimatic variables trend over the whole MRB as for individual station in the past (1961-2011) and near future (2020-2045) time periods. The results show positive seasonal and annual trend of historical mean temperature and potential evapotranspiration while a positive or negative trend in discharge and rainfall. Result finding can be used for future analysis on modeling the impacts of climate change on streamflow in MRB in order to provide a decision support package for water resource management in the basin and globally in West Africa region. Moreover, it is helpful for policy makers and water experts to advise water management policies and action plans keeping in view the findings of this study. It is important to note that such policies in developing world serious lack the scientific backing and ultimately these policies are not effectively implemented. Therefore, by incorporating and utilizing the results of these studies can bring positive results in implementation of water management policies.

Author Contributions: D.H. Koubodana, designed the study, performed the field work, data collection, developed the methodology, conducted the computer analysis and wrote the original manuscript; D.H. Koubodana and M. Tall, E. Amoussou and Muhammad Mumtaz participated to the results interpretation, rewiewing and editing original manuscript; meanwhile E. Amoussou, J. Adounkpe and K. Atchonouglo supervised the work.

Funding: We would like to thank the German Ministry of Education and Research (BMBF) for their financial support of the Graduated Research Programme of Climate Change and Water Resources at the University of Abomey Calavi, Benin through the West African Science Service Center on Climate Change and Adapted Land use (WASCAL).

Acknowledgment: We thank to Togolese and Beninese meteorological and hydrological services for providing historical climatic and discharge data for the analysis. A special thank to Climate Change Agriculture and Food Security (CCAFS) portal (http://ccafs-climate.org/data bias correction/) of International Centre for Tropical Agriculture (CIAT) for making available Global Climatic Model downscaled and bias corrected datasets that were used for our analysis.

Conflicts of Interest: The authors declare no conflict of interest.

Appendix : Annual time series in the whole MRB

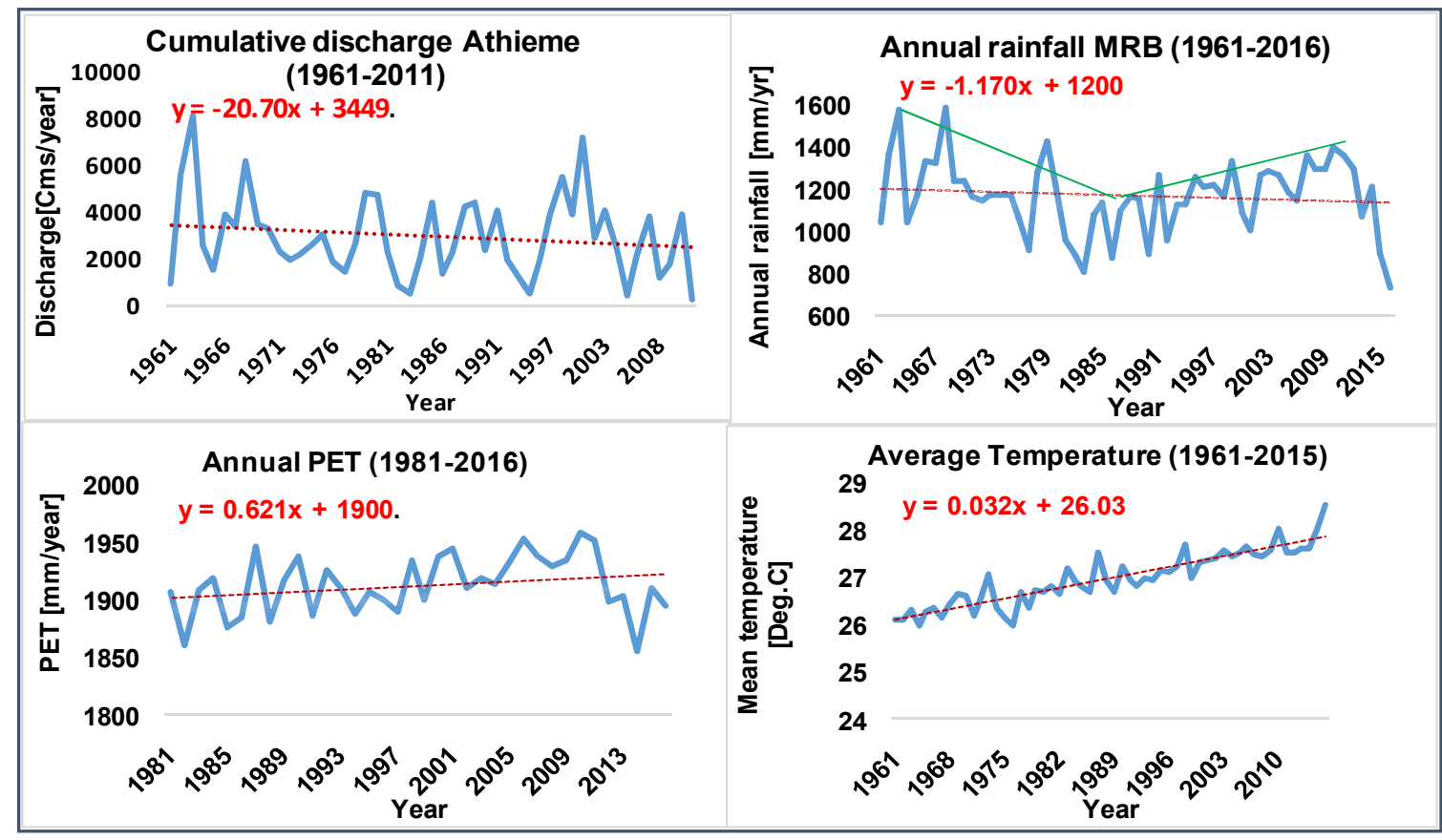




\section{References}

1. IPCC Climate Change 2014: Synthesis Report. Contribution of Working Groups I, II and III to the Fifth Assessment Report of the Intergovernmental Panel on Climate Change; Technical Report; Core Writing Team, R.K.P. and L.A.M. (eds. )]., Ed.; IPCC, Geneva, Switzerland, 2014; ISBN 9789291691432.

2. Leblanc, M.; Tweed, S.; Dijk, A. Van; Timbal, B. A review of historic and future hydrological changes in the Murray-Darling Basin. Glob. Planet. Change 2012, 80-81, 226-246.

3. Zhang, W.; Wang, Y.; Peng, H.; Li, Y.; Tang, J.; Wu, K.B. A Coupled Water Quantity - Quality Model for Water Allocation Analysis. Water Resour. Manag. 2010, 24, 485-511.

4. Yan, T.; Bai, Z. Spatial and Temporal Changes in Temperature, Precipitation, and Streamflow in the Miyun Reservoir Basin of China. Water 2017, 9, 78.

5. Koubodana, H.D. Mecanismes de connexions entre les modes de varaibilités internannuelle equatorial et meridien de l'Atlantique tropical, These de Master, Chaire Internationale en Physique Mathématique et Applications (CIPMA-Chaire UNESCO), Université d'Abomey-Calavi (UAC), Benin, Soutenu en Octobre 2015, 2015.

6. Regh, T.; Bossa, A.Y.; Diekkrüger, B. Scenario-based simulations of the impacts of rainfall variability and management options on maize production in Benin. African J. Agric. Res. 2014, 9, 3393-3410.

7. Mishra, A.K.; Singh, V.P. A review of drought concepts. J. Hydrol. 2010, 391, 202-216.

8. Nicholson, S.E. The West African Sahel: A Review of Recent Studies on the Rainfall Regime and Its Interannual Variability. ISRN Meteorol. 2013, 2013, 32 pages.

9. Ciais, P.; Sabine, C.; Bala, G.; Bopp, L.; Brovkin, V.; Canadell, J.; Chhabra, A.; DeFries, R.; Galloway, J.; Heimann, M. Climate change 2013: the physical science basis. Contribution of Working Group I to the Fifth Assessment Report of the Intergovernmental Panel on Climate Change. K., Tignor, M., Allen, SK, Boschung, J., Nauels, A., Xia, Y., Bex, V., Midgley, PM, Eds 2013.

10. Navarro-Racines, C.E.; Tarapues-Montenegro, J.E.; Ramírez-Villegas, J.A. Bias-correction in CCAFS Climate poral: Description of methodologies; Cali, Colombia., 2015;

11. Berg, P.; Feldmann, H.; Panitz, H.-J. Bias correction of high resolution regional climate model data. J. Hydrol. 2012, 448-449, 80-92.

12. Maraun, G. Bias Correction, Quantile Mapping, and Downscaling: Revisiting the Inflation Issue. J. Clim. 2013, 26, 2137-2143.

13. Onyutha, C.; Tabari, H.; Rutkowska, A.; Nyeko-Ogiramoi, P.; Willems, P. Comparison of different statistical downscaling methods for climate change rainfall projections over the Lake Victoria basin considering CMIP3 and CMIP5. J. hydro-environment Res. 2016, 12, 31-45.

14. Haerter, J.O.; Hagemann, S.; Moseley, C.; Piani, C. Climate model bias correction and the role of timescales. Hydrol. Earth Syst. Sci. 2011, 15, 1065-1079.

15. Teutschbein, C.; Seibert, J. Bias correction of regional climate model simulations for hydrological climatechange impact studies: Review and evaluation of different methods. J. Hydrol. 2012, 456-457, 12-29.

16. Gocic, M.; Trajkovic, S. Analysis of changes in meteorological variables using Mann-Kendall and Sen 's slope estimator statistical tests in Serbia. Glob. Planet. Change 2013, 100, 172-182.

17. Gosling, S.N.; Taylor, R.G.; Arnell, N.W.; Todd, M.C. A comparative analysis of projected impacts of climate change on river runoff from global and catchment-scale hydrological models. Hydrol. Earth Syst. Sci. 2011, 15, 279-294.

18. Oguntunde, P.G.; Friesen, J.; Giesen, N. Van De; Savenije, H.H.G. Hydroclimatology of the Volta River Basin in West Africa: Trends and variability from 1901 to 2002. Phys. Chem. Earth, Parts A/B/C 2006, 31, 1180-1188.

19. Diallo, I.; Sylla, M.B.; Camara, M.; Gaye, A.T. Interannual variability of rainfall over the Sahel based on multiple regional climate models simulations. Theor. Appl. Climatol. 2012, 12.

20. Amoussou, E.; Osseni, A.A.; Totin, V.S.H.; Lange, U.; Preuss, S. Hydroclimatic variability and flood risk on Naglanou and Akissa forests areas in Mono River Delta (West Africa). Int. J. Biodivers. Conserv. 2017, 9, 212223.

21. Lawin, A.E.; Hounguè, N.R.; Biaou, C.A.; Badou, D.F. Statistical Analysis of Recent and Future Rainfall and Temperature Variability in the Mono River Watershed (Benin, Togo). Climate 2019, 7, 8.

22. Lawin, A.E.; Lamboni, B.; Manirakiza, C.; Kamou, H. Future Extremes Temperature: Trends and Changes Assessment over the Mono River Basin, Togo (West Africa). J. Water Resour. Prot. 2019, 11, 82-98.

23. Wilson, D.; Hisdal, H.; Lawrence, D. Has streamflow changed in the Nordic countries? - Recent trends and comparisons to hydrological projections. J. Hydrol. 2010, 394, 334-346.

24. Kundzewicz, Z.W.; Robson, a J. Change detection in hydrological records - a review of the methodology. Hydrol. Sci. Journal-journal Des Sci. Hydrol. 2004, 49, 7-19. 
25. Houngue, R.; Lawin, E.; Moumouni, S.; Afouda, A.A. Change in Climate Extremes and Pan Evaporation Influencing Factors over Ouémé Delta in Bénin. Climate 2019, 7, 1-22.

26. Adeyeri, O.E.; Lawin, A.E.; Laux, P.; Ishola, K.A.; Ige, S.O. Analysis of climate extreme indices over the Komadugu-Yobe basin, Lake Chad region: Past and future occurrences. Weather Clim. Extrem. 2019, 23, 21.

27. PCCP Programme PCCP-from Potential Conflict to Cooperation Potential: cas du basin du Mono(Togo-Benin); Lomé-Togo, 2008;

28. Amoussou, E. Variabilite pluviometrique et dynamique hydro-sedimentaire du bassin versant du complexe fluvio-lagunaire Mono-Aheme-Couffo (Afrique de l'ouest), These de doctorat de l'Université de Bourgogne Centre de Recherches de Climatologie (CRC) CNRS - UMR 5210, soutenu le 11 mai 2010, 2010.

29. Amoussou, E.; Tramblay, Y.; Totin, H.S. V; Mahé, G.; Camberlin, P. Dynamique et modélisation des crues dans le bassin du Mono à Nangbéto (Togo / Bénin). Hydrol. Sci. J. 2014, 59, 2060-2071.

30. Koubodana, H.D.; Diekkrüger, B.; Näschen, K.; Adounkpe, J.; Atchonouglo, K. Impact of the accuracy of land cover data sets on the accuracy of land cover change scenarios in the Mono River Basin, Togo, West Africa. Preprint 2019, 2019060143, 1-23.

31. FAO FAO Statistical Yearbook 2012 Africa: Food and Agriculture; Food and Agriculture Organization of the United Nations Regional Office for Africa Accra, 2012; ISBN 9789251074268.

32. SAWES Etudes relatives a la promotion de trois (3) nouvelles organisations de bassins transfrontaliers en Afrique de l'ouest Cas du schéma du Bassin du Mono; Aougadougou, Burkina Faso, 2011;

33. Ficchì, A.; Perrin, C.; Andréassian, V. Impact of temporal resolution of inputs on hydrological model performance: An analysis based on 2400 flood events. J. Hydrol. 2016, 538, 454-470.

34. Hargreaves, G.H.; Samani, Z.A. Estimating potential evapotranspiration. J. Irrig. Drain. Div. 1982, 108, 225230.

35. Xie, H.; Longuevergne, L.; Ringler, C.; Scanlon, B.R. Calibration and evaluation of a semi-distributed watershed model of Sub-Saharan Africa using GRACE data. Hydrol. Earth Syst. Sci. 2012, 16, 3083-3099.

36. Tabari, H.; Aeini, A.; Talaee, P.H.; Some, B.S. Spatial distribution and temporal variation of reference evapotranspiration in arid and semi-arid regions of Iran. Hydrol. Process. 2012, 26, 500-512.

37. Wu, T.; Song, L.; Li, W.; Wang, Z.; Zhang, H.; Xin, X.; Zhang, Y.; Zhang, L.; Li, J.; Wu, F. An overview of BCC climate system model development and application for climate change studies. J. Meteorol. Res. 2014, $28,34-56$.

38. Giorgetta, M.A.; Jungclaus, J.; Reick, C.H.; Legutke, S.; Bader, J.; Böttinger, M.; Brovkin, V.; Crueger, T.; Esch, M.; Fieg, K. Climate and carbon cycle changes from 1850 to 2100 in MPI-ESM simulations for the Coupled Model Intercomparison Project phase 5. J. Adv. Model. Earth Syst. 2013, 5, 572-597.

39. Watanabe, S.; Hajima, T.; Sudo, K.; Nagashima, T.; Takemura, T.; Okajima, H.; Nozawa, T.; Kawase, H.; Abe, M.; Yokohata, T. MIROC-ESM 2010: Model description and basic results of CMIP5-20c3m experiments. Geosci. Model Dev. 2011, 4, 845.

40. Heuzé, C.; Heywood, K.J.; Stevens, D.P.; Ridley, J.K. Southern Ocean bottom water characteristics in CMIP5 models. Geophys. Res. Lett. 2013, 40, 1409-1414.

41. Thiessen, A.H. Precipitation averages for large areas. Mon. Weather Rev. 1911, 39, 1082-1089.

42. Memarian, H.; Balasundram, S.K.; Talib, J.B.; Sood, A.M.; Abbaspour, K.C. Trend analysis of water discharge and sediment load during the past three decades of development in the Langat basin, Malaysia Trend analysis of water discharge and sediment load during the past. Hydrol. Sci. J. 2012, 57, 1207-1222.

43. Salmi, T.; Määttä, A.; Anttila, P.; Ruoho-Airola, T.; Amnell, T. Detecting trends of annual values of atmospheric pollutants by the Mann-Kendall test and Sen's slope estimates-the Excel template application MAKESENS; Finnish Meteorological Institute (FMI): Helsinki, Finland, 2002;

44. Akpovi, K.; Antwi, E.O.; Kabo-bah, A. Impacts of Rainfall Variability, Land Use and Land Cover Change on Stream Flow of the Black Volta. Hydrology 2016, 3, 1-24.

45. Rana, A.; Foster, K.; Bosshard, T.; Olsson, J.; Bengtsson, L. Regional Studies Impact of climate change on rainfall over Mumbai using Distribution-based Scaling of Global Climate Model projections. J. Hydrol. Reg. Stud. 2014, 1, 107-128.

46. Attogouinon, A.; Lawin, A.E.; M'Po, Y.N.T.; Houngue, R. Extreme Precipitation Indices Trend Assessment over the Upper Oueme River Valley-(Benin). Hydrology 2017, 4, 36.

47. Thenmozhi, M.; Kottiswaran, S.. Aalysis of rainfall trend using Mann-Kendall test and the Sen's slope estimation in Udumalpet of future district in Tamil Nadu. Int. J. Agric. Sci. Res. 2016, 6, 131-138.

48. Sen, A.K.; Niedzielski, T. Statistical Characteristics of Riverflow Variability in the Odra River Basin, Southwestern Poland. Polish J. environement Stud. 2010, 19, 387-397.

49. Gilbert, R.O. Statistical Methods for Environmental Pollution Monitoring; John Wiley \& Sons, Inc, 605 Third Avenue, New York NY 10158M12. (212)850-6011, Fax (212) 850-6008, 1987; 
50. Anderson, M.G.; Bates, P.D. Model Validation. Perspect. Hydrol. Sci. John Wiley Sons 2001.

51. Christensen, J.H.; Kuhry, P. High-resolution regional climate model validation and permafrost simulation for the East European Russian Arctic. J. Geophys. Res. Atmos. 2000, 105, 29647-29658.

52. Moriasi, D.N.; Arnold, J.G.; Van Liew, M.W.; Binger, R.L.; Harmel, R.D.; Veith, T.L. Model evaluation guidelines for systematic quantification of accuracy in watershed simulations. Am. Soc. Agric. Biol. Eng. ISSN 2007, 50, 885-900.

53. Maraun, D.; Wetterhall, F.; Ireson, A.M.; Chandler, R.E.; Kendon, E.J.; Widmann, M.; Brienen, S.; Rust, H.W.; Sauter, T.; Al., E.; et al. Precipitation downscaling under climate change.. Recent developments to bridge the gap between dynamical models and the end user. Rev. Geophys. 2010, 1-38.

54. Martínez-Casasnovas, J.A. A spatial information technology approach for the mapping and quantification of gully erosion. Catena 2003, 50, 293-308.

55. Gudmundsson, L.; Seneviratne, S.I. Observation-based gridded runoff estimates for Europe (E-RUN version 1.1). Earth Syst. Sci. Data 2016, 8, 279-295.

56. Bogena, H.R.; Herbst, M.; Huisman, J. a.; Rosenbaum, U.; Weuthen, a.; Vereecken, H. Potential of Wireless Sensor Networks for Measuring Soil Water Content Variability. Vadose Zo. J. 2010, 9, 1002.

57. Laurent, H.; Jobard, I.; Toma, A. Validation of satellite and ground based estimates of precipitation over the Sahel. Atmos. Res. 1998, 47-48, 651-670.

58. Zhang, X.; Yang, F. RClimDex (1.0) User Guide: Climate Research Branch Environment Canada. RClimDex User Guid. Clim. Res. Branch Environ. Canada 2004.

59. Oguntunde, P.G.; Abiodun, B.J. The impact of climate change on the Niger River Basin hydroclimatology, West Africa. Clim. Dyn. 2013, 40, 81-94.

60. Halimatou, T.; Kakifa, T.; Kyei-baffour, N. Assessment of changing trends of daily precipitation and temperature extremes in Bamako and S egou in Mali from 1961- 2014 Tour. Weather Clim. Extrem. J. 2017, 18, 8-16.

61. Dashkhuu, D.; Pil, J.; Ahn, J.; Lee, W. Long-term trends in daily temperature extremes over Mongolia. Weather Clim. Extrem. 2015, 8, 26-33.

62. Oguntunde, P.G.; Abiodun, B.J.; Lischeid, G. Rainfall trends in Nigeria , 1901 - 2000. J. Hydrol. 2011, 411, 207-218.

63. Kasei, R.; Diekkrüger, B.; Leemhuis, C. Drought frequency in the Volta Basin of West Africa. Sustain. Sci. 2010, 5, 89-97.

64. Reichler, T.; Kim, J. Uncertainties in the climate mean state of global observations, reanalyses, and the GFDL climate model. J. Geophys. Res. 2008, 113, 1-13.

65. Lahsen, M. Seductive Simulations? Uncertainty Distribution Around Climate Models. Soc. Stud. Sci. 2005, 35, 895-922.

66. New, M.; Hewitson, B.; Stephenson, D.B.; Tsiga, A.; Kruger, A.; Manhique, A.; Gomez, B.; Coelho, C.A.S.; Masisi, D.N.; Kululanga, E.; et al. Evidence of trends in daily climate extremes over southern and west Africa. J. Geophys. Res. 2006, 111, 1-11.

67. Akinsanola, A.A.; Zhou, W. Projections of West African summer monsoon rainfall extremes from two CORDEX models. Clim. Dyn. 2018, 12.

68. Yabi, I.; Afouda, F. Extreme rainfall years in Benin ( West Africa ). Quat. Int. 2012, 262, 39-43. 